\title{
Siemens SOFC Test Article and Module Design
}

\author{
Final Technical Report \\ DOE Co-Operative Agreement No. DE-FE0000781 \\ Period of Performance: October 1, 2009 to March 31, 2011
}

Prepared for

National Energy Technology Laboratory

U. S. Department of Energy

by

Siemens Energy, Inc.

Stationary Fuel Cells Division

George Westinghouse Science \& Technology Center

1310 Beulah Road

Pittsburgh, PA 15235-5098

Project Manager: Joseph F. Pierre

August 2011 


\section{DISCLAIMER}

This report was prepared as an account of work sponsored by an agency of the United States Government. Neither the United States Government nor any agency thereof, nor any of their employees, makes any warranty, express or implied, or assumes any legal liability or responsibility for the accuracy, completeness, or usefulness of any information, apparatus, product, or process disclosed, or represents that its use would not infringe privately owned rights. Reference herein to any specific commercial product, process or service by trade name, trademark, manufacturer, or otherwise does not necessarily constitute or imply its endorsement, recommendation, or favoring by the United States Government or any agency thereof. The views and opinions of authors expressed herein do not necessarily state or reflect those of the United States Government or any agency thereof. 


\section{EXECUTIVE SUMMARY}

Preliminary design studies of the $95 \mathrm{kWe}$-class SOFC test article continue resulting in a stack architecture of that is $1 / 3$ of $250 \mathrm{kWe}$-class SOFC advanced module. The $95 \mathrm{kWe}-$ class test article is envisioned to house 20 bundles (eight cells per bundle) of Delta8 cells with an active length of $100 \mathrm{~cm}$. Significant progress was made in the conceptual design of the internal recirculation loop.

Flow analyses were initiated in order to optimize the bundle row length for the $250 \mathrm{kWe}-$ class advanced module. A preferred stack configuration based on acceptable flow and thermal distributions was identified. Potential module design and analysis issues associated with pressurized operation were identified. 


\section{TABLE OF CONTENTS}

Page

TASK 2.0 - ADVANCED TEST ARTICLE AND ADVANCED MODULE DESIGN..............................5

TASK 2.1 - PRELIMINARY DESIGN OF A 95 KWE-CLASS ADVANCED TEST ARTICLE ............................. 5

TASK 2.2 - PRELIMINARY DESIGN OF A 250 KWE-ClASS SOFC GeNERATOR MODULE ............................. 11

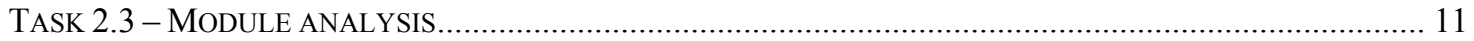

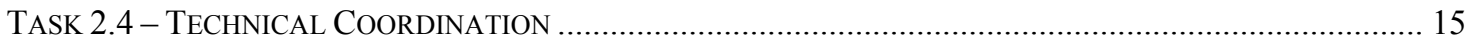

TASK 3.0 - DESIGN AND ANALYSIS OF THE POCD8R2 STACK TEST ARTICLE .....................17

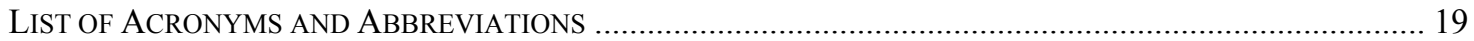




\section{Task 2.0 - Advanced Test Article and Advanced Module Design}

This task encompasses the preliminary design of a solid oxide fuel cell advanced test article and an advanced module. It will extend the technology demonstrated in the stack tests of companion program DE-FC26-05NT42613. The test article shall include two full-length bundle rows and have nominal capacity of $95 \mathrm{kWe}$. The advanced module design will extend previous work and further mature the design of a six bundle row module producing nominally $285 \mathrm{kWe}$ under atmospheric pressure conditions. The design work shall focus on an atmospheric pressure design, with additional emphasis on the specific stack components that would be impacted in adapting the design for pressurized operation.

Work on this task was initiated under the companion program and was subsequently redirected to this program. The activities completed under the companion program are included herein with no distinction being made between the two respective efforts.

\section{TASK 2.1 - PRELIMINARY DESIGN OF A 95 kWe-CLASS ADVANCED TEST ARTICLE}

The objective of this task is to develop the preliminary design of $95 \mathrm{kWe}$-class advanced stack test article based on the Delta8 cell technology. This shall include the preliminary design of the following:

- Fuel delivery system and anode recirculation system

- Air/exhaust collection system

- Test article instrumentation

- Power system components

- Start-up heater

- Test article containment

- Peripheral insulation system

- Recirculation loop.

Furthermore, the preliminary designs shall be, where applicable, scalable to the 285 kWe-class advanced module.

The $285 \mathrm{kWe}$-class advanced module features an air inlet manifold along with an exhaust plenum, which distribute process air and collect exhaust air respectively along the bundle row. The distribution and collection of the exhaust along the bundle row leads ultimately to a flow mal-distribution and a temperature variation within the bundles in a bundle row due to the static pressure variation in the respective manifolds. In addition, the variation in bundle air flows along with the side recirculation collection induce stack 
and combustion zone fuel flow variations, which can further aggravate the stack temperature distribution thereby limiting its performance.

The flow maldistributions arising from the process air distribution and exhaust flow collection can be mitigated to acceptable levels by decreasing the number of bundles in a bundle row while increasing the number of bundle rows. However, transverse stack flow variation increases since the process air is distributed between bundle rows. Also addition of bundle rows can lead to further costs due to increased row-connects and increased number of serial manufacturing operations. The objective of this analysis is to seek the optimum bundle row and stack configuration for the $285 \mathrm{kWe}$ advanced module and to define the $95 \mathrm{kWe}$ test article to serve effectively in validating the $285 \mathrm{kWe}$ module design. A network model of the various airflow paths and fuel flow paths along a bundle row were developed using the network software SINDA/FLUINT.

A model of the flow networks present within a bundle row was developed using the fluid/thermal network software SINDA/FLUINT and is shown in Figure 1.1, where stack locations represented by nodes are connected by air flow paths whose flow resistances are calculated based on the stack components in the path. It should be noted that the present advanced module features ten bundles in a row, which is considered to be the upper limit of the number of bundles within a bundle row based on previous evaluations. The airflow resistances of the exhaust manifold (formed by the exhaust castings), the combustion zone, and the recuperator were evaluated using detailed CFD models as highlighted in the Figure. The flow resistance of the cell stack was also obtained from a CFD model of the cell that was developed earlier. The pressure drops variation in the air inlet manifold and the exhaust manifold were modeled using correlations from Idelchik. Note that temperature variations due to flow variations and the corresponding feedback were not included in these calculations and will be taken into account in future models. Both the syngas and natural gases are being analyzed, the latter could have a pronounced fuel distribution effect due to the higher anode off-gas recirculation flows as compared to the former where the air flow and exhaust flows tend to dominate.

The variation of fuel and air flows along the bundle row for the coal gas are shown in Figure 1.2 for the maximum current case of $1432 \mathrm{~A}$. It is clear from this figure that while the airflow and exhaust flow distributions are somewhat acceptable with an air inlet orifice pressure drop of 5 in of $\mathrm{H}_{2} \mathrm{O}$, stack fuel flow distribution and the distribution of the depleted flow into the combustion zone are well above acceptable limits, in particular considering a fuel consumption of $88 \%$ for the syngas case. A graded air inlet orifice configuration along the bundle row only aids in making the airflow and exhaust flow distributions more uniform and does not improve the relevant fuel flows as shown in Figure 1.3. A better overall flow distribution is obtained if an exhaust side resistance is used in lieu of the air side orifice as shown in Figure 1.4. However, the practicality of placing a resistance on the exhaust side needs to be investigated. The corresponding results of Figure 1.2 for the natural gas case at its maximum current of $1173 \mathrm{~A}$ are shown in Figure 1.5 and vary in a fashion similar to that of the syngas.

A further objective is to develop a design concept of an internal recirculation loop for the $95 \mathrm{kWe}$-class test article which is scalable for the $285 \mathrm{kWe}$-class advanced module. 
A study was initiated as an attempt to identify new cost effective design solutions for the advanced module with internal recirculation loop suitable for implementation in coalbased fuel cell systems. The design strategy was to develop a solution that consolidates all the loop components into one compact configuration solution. Instead of having external separate components for fuel heaters, circulator, pre-reformer, ejector and hot piping, the most recent design incorporates all these components into one integrated system which is housed inside the container and peripheral insulation system. The primary advantage of this concept is better utilization of the existing internal volumes, reduction of insulation and support structures and ultimately lower cost.

High temperature circulator, gas burner and means of distributing fuel uniformly to the cells received the most attention because they are critical for a successful advanced module design.

Preliminary design studies of the $95 \mathrm{kWe}$-class test article were conducted and a detailed stack architecture of $1 / 3$ of the advanced module stack including an internal recirculation loop was developed for internal reviews. The design approach was to develop a highly integrated SOFC stack by scaling up the existing design of the two-row POCD8R1 test article to include 20 bundles arranged in two rows of ten bundles each, with the addition of an internal recirculation loop.

The outer container is sized to accommodate a $285 \mathrm{~kW}$ stack with six rows of ten bundles each, for a total of 480 Delta8 cells. The same container, with appropriate partitioning, can accommodate $1 / 3$ of a stack or two rows of ten bundles each, 160 Delta8 cells in total. An isometric model of the container is shown in Figure 1.6. Figure 1.7 is a detail sectional view showing the internal recirculation loop and fuel flow paths.

The $95 \mathrm{kWe}$ test article will house 20 bundles of eight Delta8 cells, $100 \mathrm{~cm}$ active length, and will be integrated with an internal recirculation loop comprising a gas-fired burner for preheating the fuel side during startup, a high temperature circulator fan, extended side recirculation zone (SRZ) ducts and a recirculation plenum-pre-reformer installed on one end of the stack. Balance-of-plant (BOP) equipment related to process air, fuel and purge gas supply, module exhaust, and DC-to-AC power conditioning will complete the configuration of the test article.

\section{Internal Recirculation Loop}

For a natural gas application, typically $2 / 3$ of the spent fuel exiting the stack, rich in water vapor $(\sim 50 \%)$ and carbon-dioxide $(28 \%)$, is recirculated throughout the recirculation loop to provide the oxidizer required for fuel reformation in addition to inhibiting carbon deposition in the internal reformer. In a syngas application, only $1 / 10$ of the anode gas is circulated, just enough to completely reform the small percentage (3-5\%) of methane typically present in the syngas composition. However, during start-up of the unit, a large flow of gas is circulated through the loop to preheat the stack by the addition of heat provided by fuel heaters.

The key requirements for the internal recirculation loop design are:

- Provide heat and gas flow for startup heating and stack operation

- Incorporate a start-up heater which must be gas-fired (not electric) 
- Provide sufficient pressure head to circulate recirculation flow

- Provide pre-reforming of the incoming hydrocarbon fuel and sufficient pressure head/flow through reforming catalyst bed

- Provide adequate NHmix purge flow during startup and shutdown

- Support maximum current conditions, namely: $1432 \mathrm{~A}\left(\mathrm{~J}=.55 \mathrm{~A} / \mathrm{cm}^{2}\right)$ on syngas, $1171 \mathrm{~A}\left(\mathrm{~J}=.45 \mathrm{~A} / \mathrm{cm}^{2}\right)$ on natural gas

- Ensure uniform mixing of fresh fuel and recirculation gas and provide uniform inlet flow distribution to the stack

- Materials compatible with SOFC reducing environment and high temperatures

- Accommodate differential thermal expansion between components .

The internal recirculation loop includes a centrifugal circulator, twin start-up burners, an integral recirculation plenum with pre-reformer and fuel mixing tube.

A rendering of the internal recirculation loop comprehensive of all the components is shown in Figure 1.8.

\section{High Temperature Circulator}

Conventional SOFC modules produced to date have employed an ejector pump, or a parallel-connected array of such units, for purposes of recirculating anode gas and freshly reformed fuel gas throughout the stack. Incoming fresh fuel is the motive gas used to drive the ejector which is essentially a fixed operation point device. Unfortunately, a compressor is required to elevate the fuel pressure to the required level at entry to the ejector nozzle. POCD8R1 was the first test article to incorporate a combination of ejector and high temperature circulator both mounted externally to the container in a separate recirculation loop.

Preliminary operating experience with the POCD8R1 circulator appears to be largely positive. The unit was capable to startup the module by recirculating a large volumetric flow rate of $\mathrm{NHmix}$ and subsequently hydrated hydrogen successfully demonstrating gas side startup heating. The ejector was never used during operation and the entire anode gas recirculation was handled by the circulator.

The POCD8R1 circulator was a small unit acquired from Creative Applications (CAP) of Japan for experimentation in a $5 \mathrm{~kW}$ SOFC system. The unit was refurbished and certain design modifications, such as the addition of a metallic scroll and interface inlet/outlet nozzles, were implemented by CAP.

The preferred configuration locates the circulator downstream of the reformer where the gas temperature is at its lowest. Vertical orientation of the rotor shaft vertical is the best configuration to simplify bearing design. This configuration greatly simplifies assembly and servicing of the component, including motor and seals maintenance. Figures 1.9 illustrates this arrangement.

An important aspect of the design of a fuel gas circulator is the volute chamber that surrounds the $360 \mathrm{~mm}$ (14") diameter impeller. In this zone, the kinetic energy associated with the gas leaving the impeller is recovered as potential energy, or head. Ideally, volute chambers take the shape of logarithmic spirals. A 4-point discharge 
volute directs the flow into passages that are formed in a squared ceramic board. These passages feed into the fuel plenum below that turn the fuel gas stream downward to a lower level along the right and left hand sides of the ceramic board, in correspondence to the entrance of the fuel heater section.

The volute chamber design must be compatible with the impeller and with the constraints that are placed upon how the gas flow must be directed after it leaves the circulator. These constraints are imposed by the overall design of the internal recirculation loop. In view of this, a volute chamber having 4 discharge points was found to be most satisfactory. Figure 1.10 shows the detail of the volute chamber.

The most important functional requirements for the $95 \mathrm{~kW}$ circulator are:

- Circulator shall be a direct drive type with sealed shaft or magnetically coupled to the motor

- Shaft seals shall be compatible with the pumped gases and the operating temperatures and pressures expected in normal and abnormal operation and during normal and emergency shutdowns. Shaft seals shall be designed such that hazardous $\mathrm{CO}$ gas leakage is avoided.

- Passive cooling shall be used for bearings or seals

- Circulator speed modulation shall be achieved by a high efficiency variable frequency $A C$ drive.

Circulator specifications for the $95 \mathrm{kWe}$ test article gas composition, temperature, and flow rates are shown in Figure 1.11. Performance curves supplied by the vendor are also shown.

\section{Start-up Heater}

The start-up heater is designed to provide fuel side start-up heating and supplemental heating for natural gas pre-reforming. POCD8R1 employed a series of electric heaters installed in the external recirculation loop, downstream of the ejector-circulator section. For the 95 and $285 \mathrm{~kW}$ systems, it would be preferable to use gas-fired heaters to avoid the need to have high power electricity demand at a test site.

The choice fell on single-ended recuperative (SER) burners for a number of reasons, primarily reliability, since technology for radiant tube furnaces with controlled atmospheres fired with fossil fuels has been part of standard furnace design for at least 60 years, and secondly efficiency, since recuperative air preheating is accepted as the most effective way to increase energy efficiency for high-temperature process heating. In addition, there are many suppliers of gas-fired radiant tubes and the technology is widely used in the furnace heating industry.

In a SER burner, fresh air and fuel are combusted in an inner tube within a burner assembly while exiting exhaust gases are recovered, passed back through an outer tube that surrounds the inner tube and used to heat the incoming fresh air in a recuperator region.

The functional requirements for the $95 \mathrm{~kW}$ start-up heaters are:

- Indirect heating of the following gases: 
- $\quad$ Air (up to $400^{\circ} \mathrm{C}$ )

- $95 \%$ nitrogen $/ 5 \%$ hydrogen mix (from 400 to $950^{\circ} \mathrm{C}$ )

- Unreformed fuel with the following gas composition (from 600 to $950^{\circ} \mathrm{C}$ )

$\mathrm{H}_{2} \quad 28 \%$ (volume fraction)

$\mathrm{CO} \quad 12 \%$

$\mathrm{H}_{2} \mathrm{O} \quad 32 \%$

$\mathrm{CO}_{2} \quad 18 \%$

$\mathrm{N}_{2} \quad 1 \%$

$\mathrm{C}_{\mathrm{x}} \mathrm{H}_{\mathrm{y}} \quad 9 \%$

- Preheated gas mass flow range: 3000 slpm NHmix, 4300 slpm unreformed fuel

- Total heat required with 2 burner: 24 kW ( 342,000 Btu/hr) net

- Fuel: natural gas

The burner system which best meets the above requirements is a Kanthal Ecothal 4-20 SER burner. For the $95 \mathrm{~kW}$ test article, a twin SER burner system with the following characteristics was selected:

- Gross power consumption: $20 \mathrm{~kW}(68,300 \mathrm{BTU} / \mathrm{hr})$

- Max. net power: $\quad 16 \mathrm{~kW}(54,600 \mathrm{BTU} / \mathrm{hr})$

- Max. efficiency: $\quad 80 \%$

- Min. net power: $\quad 6.4 \mathrm{~kW}(21,800 \mathrm{BTU} / \mathrm{hr}) \mathrm{min}$. controllable firing rate

- Turn down ratio:

2.5

Figure 1.12 is a rendering of the SER burner assembly showing the inner tube, outer tube, exhaust housing, and internal recuperator.

In summary, significant progress was made in the conceptual design of the internal recirculation loop for the $95 \mathrm{~kW}$ test article. A detail model was developed in Pro/Engineer software and the assembly sequence of the internal loop components was studied in great detail.

Key components of the recirculation loop such as circulator and gas burner were sized for a 20 bundle/160 Delta8 cell stack configuration. A number of design simplifications and improvements were made to the existing POCD8R1 recirculation loop and module container. Significant interaction took place with Suppliers of high temperature circulator and gas-fired burners. Preliminary quotes were received and technical discussions were initiated to finalize the design of the components.

In all these activities, there was a concerted effort to develop a number of new innovative features that are aimed at reducing the manufacturing and assembly cost and providing greater compactness to the Module than any other previous design approaches.

A specific objective of this effort was to determine a module architecture that is most advantageous with respect to module capital cost and aggregation of multiple modules to form a large SOFC system. This objective has been accomplished as a module 
architecture has been defined that provides an efficient internal packaging of the recirculation loop. The internal recirculation loop concept is scalable and it is applicable to both 95 and $285 \mathrm{~kW}$ test articles. Particular effort was spent in designing for servicing.

\section{TASK 2.2 - PRELIMINARY DESIGN OF A 250 kWe-CLASS SOFC GENERATOR MODULE}

The work in this task applies to specific design features of the $285 \mathrm{kWe}$ advanced module design. The current focus of the stack concept development is in the determination of the optimum bundle row length, incorporation of the functionality of the POCD8R1 external recirculation loop inside the container, and selection and design integration of a gas fired fuel side heater.

Flow analyses were completed to optimize the bundle row length. See the following discussion in Task 2. for detailed analysis information. Conceptual design work was completed incorporating the new bundle row length into the module design. The original advanced module design contained a ten bundle row length, with a total of six rows as shown in Figure 1.13. Based on flow analyses, the proposed row length consists of six bundles in a row, with a total of 10 rows, see Figure 1.14. Preliminary layout work was completed and no major module design obstacles were identified

An ASPEN system model developed previously to evaluate the $250 \mathrm{kWe}$-class module was updated using the latest available measurements of stack internal electrical connector losses.

The cell-cell connector losses, the bundle to bundle connector losses, the row-row connector losses, and the bus bar losses were evaluated based on available test data from a two cell Delta8 cell test and from the POCD8R1 stack test. The resistances were then used to update the $250 \mathrm{kWe}$ system performance reported in the previous period. The resistance indices based on the cell active area for the various components are listed in Table 1.1.

The updated preliminary system performances for the syngas and natural gas for the $250 \mathrm{kWe}$-class module are shown Tables 1.2 and 1.3 respectively.

\section{TASK 2.3 - MODULE ANALYSIS}

The system model developed for the POCD8R1 test article using the ASPEN system analysis software was extended to model the $95 \mathrm{kWe}$ test article and the $285 \mathrm{kWe}$ advanced model. Both natural gas and syngas fuel inputs were considered in determining the air and fuel flow rates for these units. The syngas fuel corresponds to the composition entering the stack in the coal gas fueled baseline system conceptualized in Phase I and was simulated using a mixture of hydrogen, natural gas, and NHMIX, in accordance with the planned POCD8R1 testing. The performance maps developed for the Delta8 cell were used in evaluating the system performance. The POCD8R1 recuperator model was assumed in these models and the corresponding 
recuperator effectiveness vs. cell air flow profile was integrated with the cell performance map to determine the required cell-stack air flow rate, given input values for the cell current and the desired average cell temperature, and the prevailing module air inlet temperature. Resulting from the calculation (in addition to air and fuel flow rate) are estimates of cell voltage, peak cell temperature, and maximum-to-minimum axial cell temperature differential, as well as estimates of the system electric performance parameters.

The key assumptions used in evaluating the systems for both the fuels are listed in Table 1.4, while Table 1.5 lists other inputs which are specific to the fuel under consideration. The air bypass allowance and the fuel bypass allowance are assumed to be $5 \%$ for the $95 \mathrm{kWe}$ unit, typical values used in evaluating the POCD8R1 system performance, although significantly lower values have been predicted in component analyses. The fuel bypass is assumed to be about $1.5 \%$ for the $285 \mathrm{kWe}$ unit, which is typical for generators of its size. The recirculator blower parasitic was not included in these calculations as its characteristics are not known presently. In addition, the module heat loss and the I \& C losses were approximately estimated based on historically used values. It should be noted that the stack inlet temperature was fixed as per Table 1.5.

Results of these preliminary analyses including a listing of the fuel and air flow rates and the system electrical performance over the operating range of the $95 \mathrm{kWe}$ and the 285 kWe units are shown in Table 1.6 for both fuels. Temperatures at key locations in the module are also shown in the table. System temperature maps at the nominal current density of $320 \mathrm{~mA} / \mathrm{cm}^{2}$ are shown in Figure 1.15 and Figure 1.16, respectively, for the 95 $\mathrm{kWe}$ test article for the syngas and natural gas cases. Statepoint listings at locations corresponding to these figures are provided in Tables 1.7 and 1.8.

The flow network model of the bundle row that was developed using the software SINDA/FLUINT in the previous reporting period was extended to include cell thermal characteristics to simulate expected thermal feedback effects. The number of bundles in the bundle row was varied to seek the optimal stack configuration from a flow and thermal distribution perspective.

In addition, potential module design and analysis issues and concerns associated with pressurized operation were identified and listed.

The flow network model of a ten bundle row developed using the fluid/thermal network software SINDA/FLUINT is shown in Figure 1.18, where stack locations represented by nodes are connected by air flow paths whose flow resistances are calculated based on the stack components in the path. It should be noted that the present advanced module design features 10 bundles in a row, which is considered to be the upper limit of the number of bundles within a bundle row based on previous evaluations. The airflow resistances of the exhaust manifold (formed by the exhaust castings), the combustion zone, and the recuperator were evaluated using detailed CFD models as highlighted in Figure 1.18. The flow resistance of the cell stack was also obtained from a CFD model of the cell that was developed earlier. The pressure drop variation in the air inlet manifold was modeled using correlations from Idelchik. 
The stack flow resistance was calculated from a multivariate regression expression developed based on a detailed model of the cell developed earlier using the CFD software Fluent. In general,

where Sair , I, FC, \& OTC denote the air stoichs (1/air utilization), the cell current, the

$$
\begin{gathered}
\Delta P_{\text {air-side-cell }}=f\left(T_{\text {air-in-cell }}, S_{\text {air }}, I, F C, \text { OTC }\right) \\
T_{\text {ave }}=f\left(T_{\text {air-in-cell }}, S_{\text {air }}, I, F C, \text { OTC }\right) \\
V_{\text {cell }}=f\left(T_{\text {air-in-cell }}, S_{\text {air }}, I, F C, \text { OTC }\right) \\
T_{\text {cell-peak }}=f\left(T_{\text {air-in-cell }}, S_{\text {air }}, I, F C, \text { OTC }\right) \\
\Delta P_{\text {fuel-side-cell }}=f\left(T_{\text {air-in-cell }}, S_{\text {air }}, I, F C, O T C\right) \\
T_{\text {air-out-cell }}=f\left(T_{\text {air-in-cell }}, S_{\text {air }}, I, F C, O T C\right)
\end{gathered}
$$

fuel consumption, and the oxygen to carbon ratio in the recirculation (in essence the recirculation flow rate) respectively. For a given FC and OTC, maps representing the relevant cell characteristics were developed using a surface response approach. A multivariate regression surface of the general form,

$$
\begin{aligned}
& X=C_{o}+C_{1} I+C_{2} S_{\text {air }}+C_{3} T_{\text {air-in-cell }}+C_{4} I^{2}+C_{5} S_{\text {air }}^{2}+C_{6} T_{\text {air-in-cell }}^{2}+C_{7} I S_{\text {air }} \\
& +C_{8} I T_{\text {air-in-cell }}+C_{9} S_{\text {air }} T_{\text {air-in-cell }}
\end{aligned}
$$

that includes quadratic and interaction terms was fitted to the data generated using Fluent. Figure 1.19 shows examples of the maps for the syngas fuel at the maximum current of $1432 \mathrm{~A}$.

In conjunction with an expression for the internal recuperator effectiveness as a function of the flow, the cell thermal conditions can be calculated using the regression equations. By using the expression for the cell air side $\mathrm{dP}$ in the flow network model of Figure 1.18, it is possible to couple indirectly the simplified network model, which is quite sufficient for other flow components in the stack, with a comprehensive Fluent model. Note that this coupling automatically models any thermal feedback effects. The fuel feedback effect on the temperature distribution is not included at this optimization stage although it will be considered once an optimal configuration is determined. The cell voltage, the cell peak temperature and other relevant cell parameters can also be obtained once the flow network and the multivariate regression models have converged.

Both the syngas and the natural gas fuels were considered in these investigations. Figure 1.20 shows the relevant flow distribution normalized by the corresponding 
average flow for the coal gas case at the maximum condition. The corresponding stack temperature and cell voltage variations are shown in Figure 1.21. Note that the total airflow was adjusted so that the peak cell temperature is about $970 \mathrm{C}$. While the process air flow distribution and the cell temperature distribution appear to be within acceptable limits the flow mal-distributions of the stack fuel and of the depleted fuel flow into the combustion zone $(\mathrm{CZ})$ are not desirable. The results for the ten bundle row are summarized in Table1.9, which shows that the mal-distributions, characterized by the minimum and the maximum deviations from the average, only vary slightly with cell current. It is also evident from the table that an air inlet orifice is not effective in mitigating the stack and depleted fuel flow mal-distributions. Reducing the exhaust collection pressure drop or the introduction of an exhaust side pressure drop downstream of the internal recuperator has a beneficial effect on the flow distributions, as seen in Table 1.10, which shows the sensitivity of the flow and temperature maldistributions to some relevant model parameters. The flow and temperature distributions for the natural gas case for the ten bundle row, shown in Figures 1.22 and 1.23 at the max current of $1171 \mathrm{~A}$, are relatively better than the distributions shown in Figures 1.20 and 1.21 for the coal gas case, due to the lower air flow rates in addition to the higher stack fuel recirculation rates. However, the stack fuel flow and the depleted fuel flow distributions are not still within the desirable limits. The results for the natural gas case for the ten bundle row at different currents are summarized in Table 1.11 as for the syngas case, which again shows the ineffectuality of the air inlet orifice in smoothing the flow variations.

Decreasing the number of bundles in a bundle row decreases both the air distribution pressure drop and the exhaust collection pressure drop, which are beneficial in mitigating flow mal-distributions, as shown in Tables 1.12 and 1.13, where results are summarized for number of bundles in a row varying from five to ten at different currents for the syngas and natural gas fuels respectively. The variation of the flow and temperature mal-distributions are shown graphically in Figures 1.24 and 1.25 respectively for the syngas fuel at a current of $1432 \mathrm{~A}$ and for the natural gas fuel at $1171 \mathrm{~A}$. It is clear from these tables and figures that a six bundle row configuration is preferable to limit the stack fuel flow and depleted fuel flow into CZ maldistributions to within $\pm 2 \%$ and $\pm 5 \%$ while limiting the stack temperature variation to less than $10 \mathrm{C}$ for both the fuels. A preliminary design investigation shows that the outer canister aspect ratio is more favorable for the 6 bundle row case (with 10 bundle rows in all to make for the $285 \mathrm{~kW}$ ) without increasing the parts count drastically. Also, with the 6 bundle row configuration, the air and fuel flow distribution to the bundle rows spans 5 rows on each side and can become limiting as the number of bundle rows increase.

\section{Identification of module design and analysis issues for pressurized operation}

Pressurization of the module entails changes to the module design. Potential design and analysis issues associated with pressurized operation were identified and a preliminary listing is provided in Table 1.14. It should be noted that this list is only preliminary and will be updated depending on specific design requirements.

A preferred stack configuration, which was found to be optimal from a flow and temperature distribution perspective, was recommended. Potential module design and analysis issues associated with pressurized operation were identified and listed. 
The effect of bundle row length on stack thermal and flow distribution was investigated culminating in the recommendation of an optimal stack configuration. It was also found that the air inlet orifice was not effective in mitigating fuel flow maldistributions.

\section{TASK 2.4 - TECHNICAL COORDINATION}

No significant activity to report this quarter. 


\section{TASK 3.0 - Design and Analysis of the POCD8R2 Stack Test Article}

No significant activity to report this quarter. 


\section{LIST OF ACRONYMS AND ABBREVIATIONS}

$\begin{array}{ll}\text { BOP } & \text { Balance-of-plant } \\ \text { CTE } & \text { Coefficient of Thermal Expansion } \\ \text { EDS } & \text { Energy Dispersive Spectroscopy } \\ \text { EGA } & \text { Evolved Gas Analysis } \\ \text { EL } & \text { Electrolyte } \\ \text { FE } & \text { Fuel Electrode } \\ \text { H } & \text { Hydrogen } \\ \text { HPD } & \text { High power density } \\ \text { HTL } & \text { High Temperature Leak Rate } \\ \text { I\&CS } & \text { Instrumentation and Control System } \\ \text { I/O } & \text { Input/Output } \\ \text { IC } & \text { Interconnection } \\ \text { IL } & \text { Interlayer } \\ \text { NH } & \text { nitrogen hydrogen mixture } \\ \text { NHMIX } & \text { 95\% Nitrogen/ 5\% Hydrogen } \\ \text { OLE } & \text { Object Linking and Embedding } \\ \text { OPC } & \text { OLE for Process Control } \\ \text { P\&ID } & \text { Process and Instrumentation Diagram } \\ \text { Pcf } & \text { pounds per cubic foot } \\ \text { PLC } & \text { Programmable Logic Controller } \\ \text { POC } & \text { Proof-Of-Concept } \\ \text { Ppm } & \text { part per million } \\ \text { RBS } & \text { Rutherford Back Scattering } \\ \text { SCG } & \text { Slow Crack Growth } \\ \text { SCR } & \text { Silicon Controlled Rectifier } \\ \text { ScSZ } & \text { Scandia stabilized zirconia } \\ \text { SEM } & \text { Scanning Electron Microscope } \\ \text { SER } & \text { single-ended recuperative burner } \\ \text { SFC } & \text { Stationary Fuel Cells } \\ \text { SIS-D8 } & \text { Siemens Imaging System for Delta-8 Bundle Open Ends } \\ \text { SIS-D8 DA } & \text { Data analysis and GUl component of SISD-D8 } \\ \text { SIS-D8 IA } & \text { Image acquisition component of SIS-D8 } \\ \text { SIpm } & \text { standard liters per minute } \\ \text { SOFC } & \text { Solid Oxide Fuel Cell } \\ \text { SOW } & \text { Statement of Work } \\ \text { SRZ } & \text { Side Recirculation Zone } \\ \text { TA } & \text { Test Article } \\ \text { TGA } & \text { Thermal Gravimetric Analyzer } \\ \text { TGA-MS } & \text { Thermal Gravimetric Analysis - Mass Spectroscopy } \\ \text { UPS } & \text { Uninterruptable Power Supply } \\ \text { XPS } & \text { X-ray Photoelectron Spectroscopy } \\ \text { XRD } & \text { X-ray Diffraction } \\ & \end{array}$




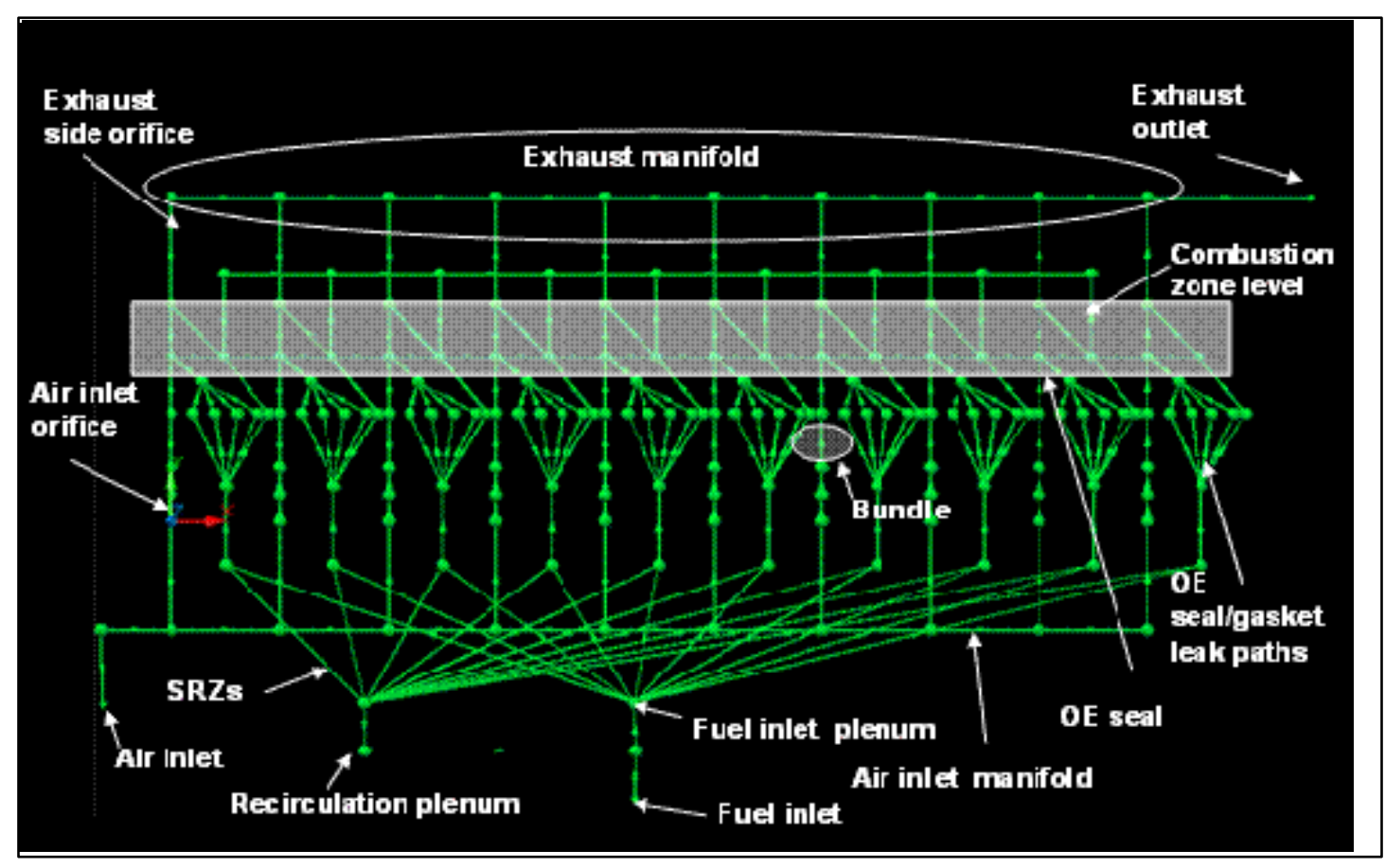

Figure 1.1 - SINDA/FLUINT Flow Network of a Ten Bundle - Bundle Row

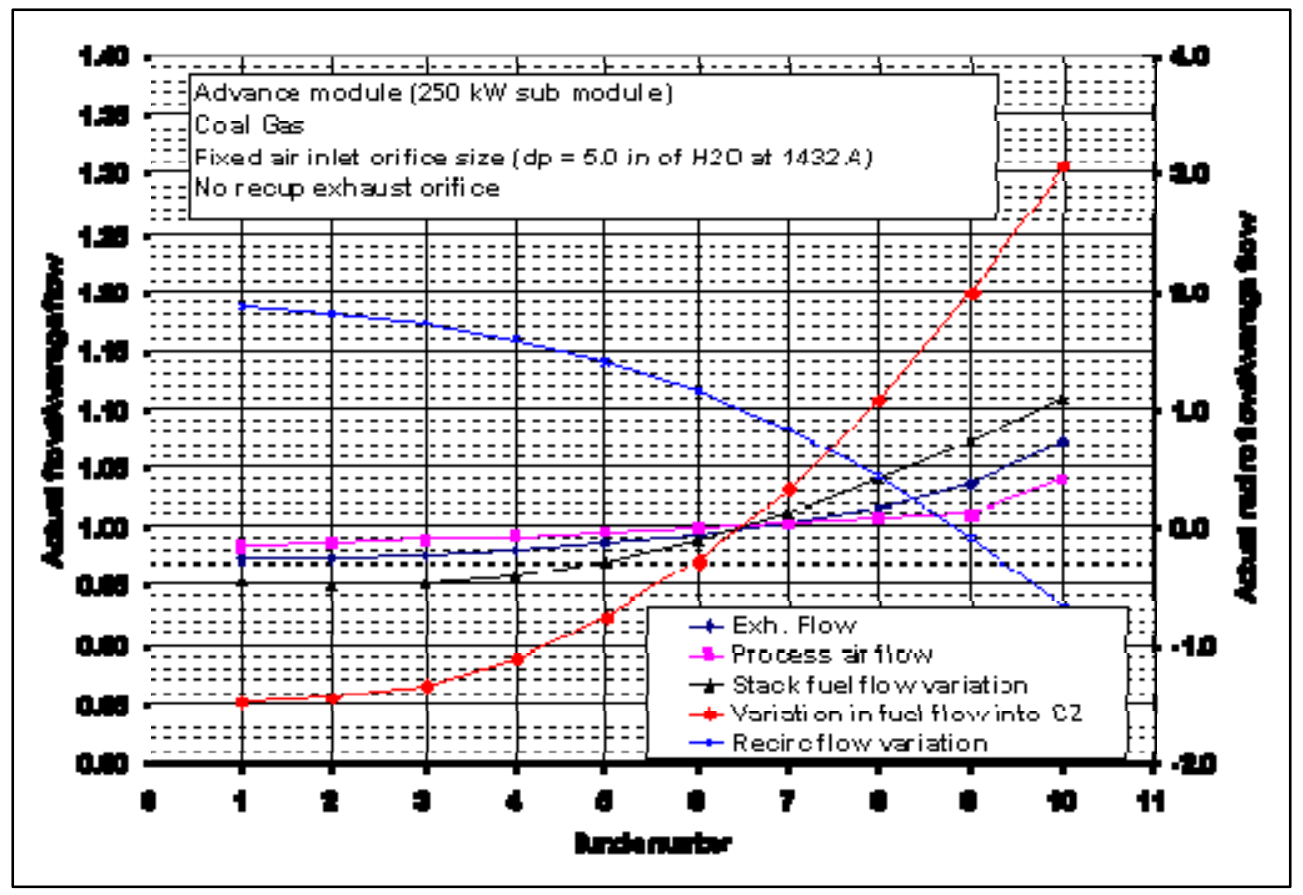

Figure 1.2 - Flow Distribution for Syngas Case (I = $1432 \mathrm{~A}$, air inlet orifice $\mathrm{dP}=5$ in of $\mathrm{H} 2 \mathrm{O}$ 


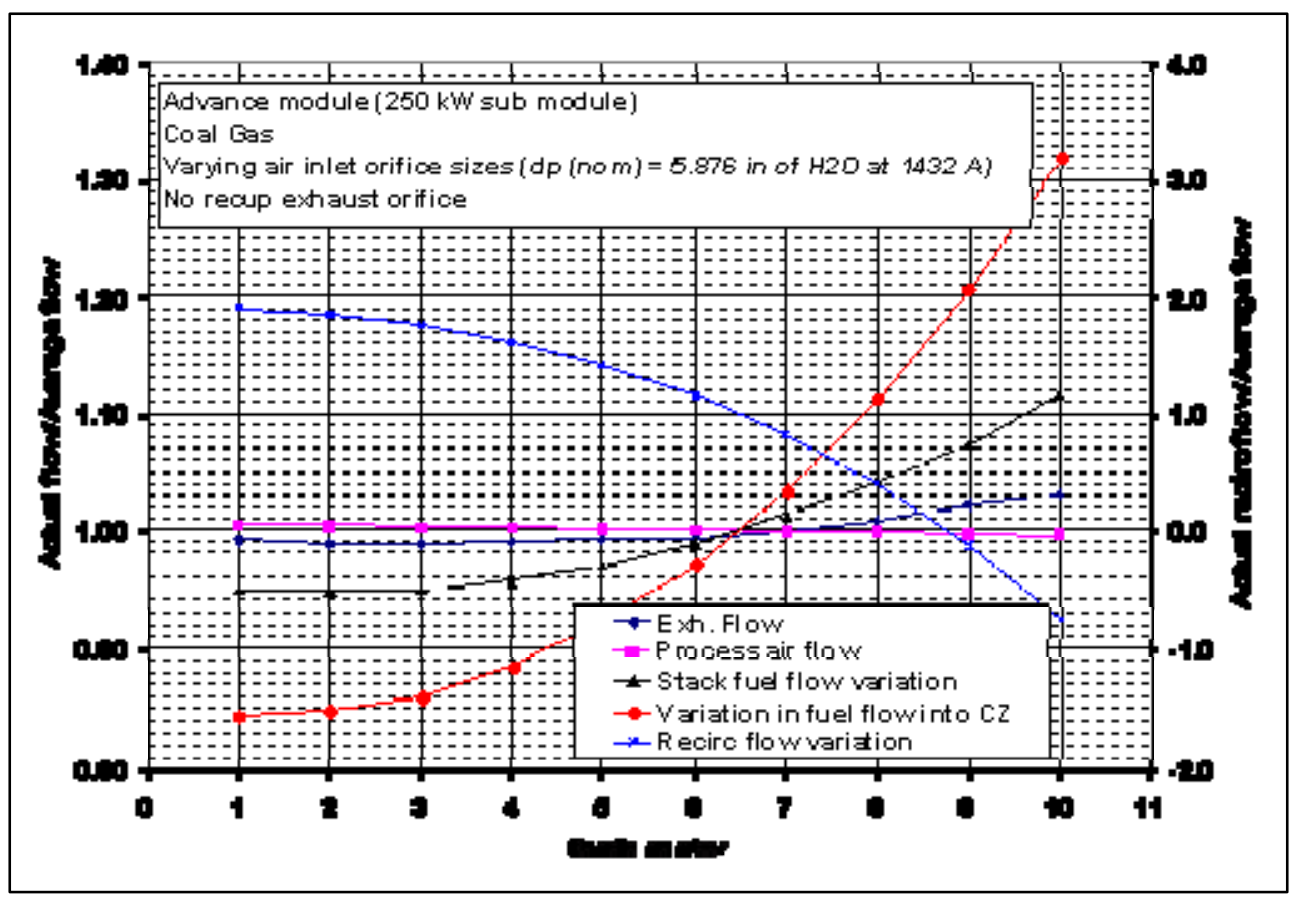

Figure 1.3 - Flow Distribution for Syngas Case ( $I=1432 \mathrm{~A}$, air inlet orifice dP varying, nominal $d P=5.876$ in of $\mathrm{H} 2 \mathrm{O}$ )

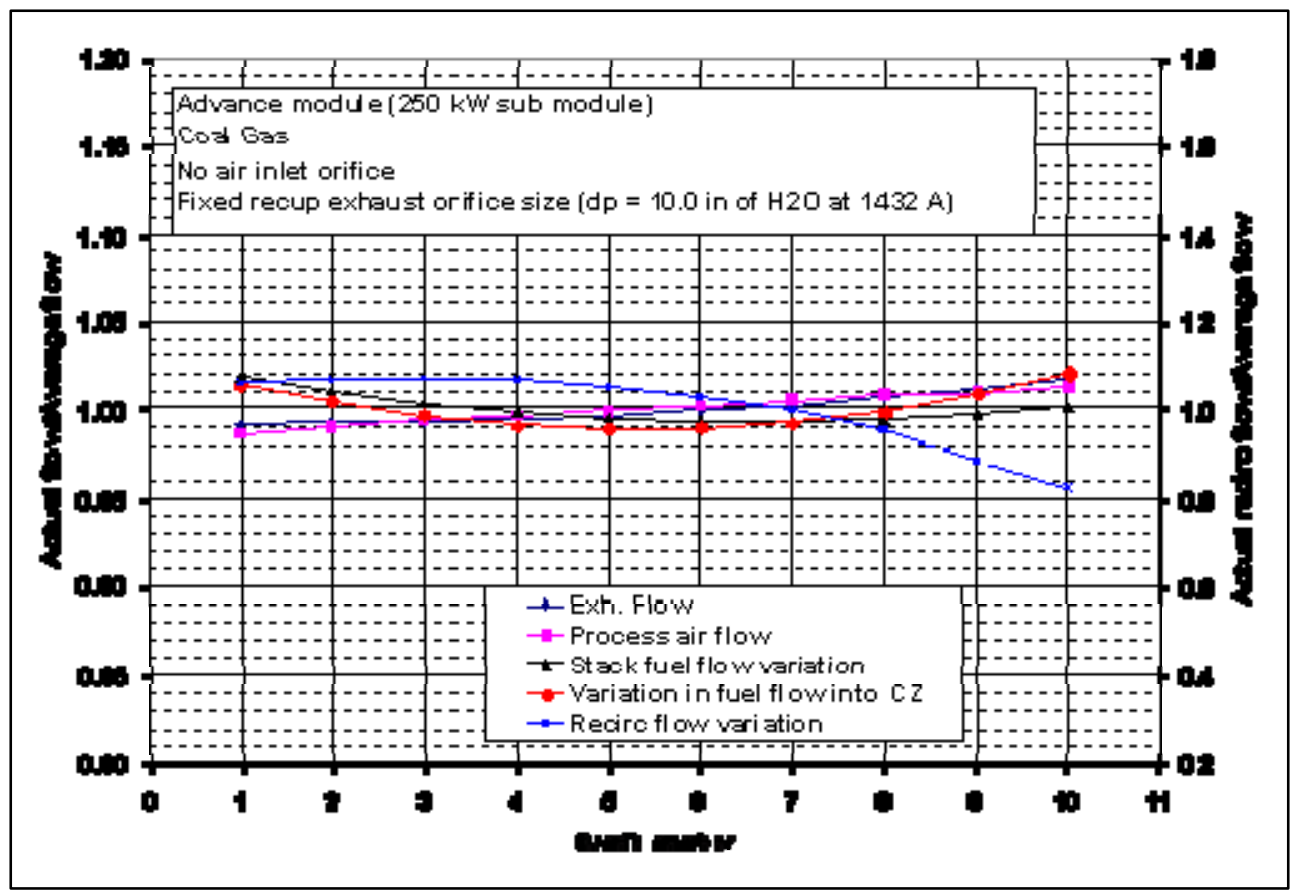

Figure 1.4 - Flow Distribution for Syngas case ( $\mathrm{I}=1432 \mathrm{~A}$, No air inlet orifice, Exhaust side orifice $\mathrm{dP}=10$ in of $\mathrm{H} 2 \mathrm{O}$ ) 


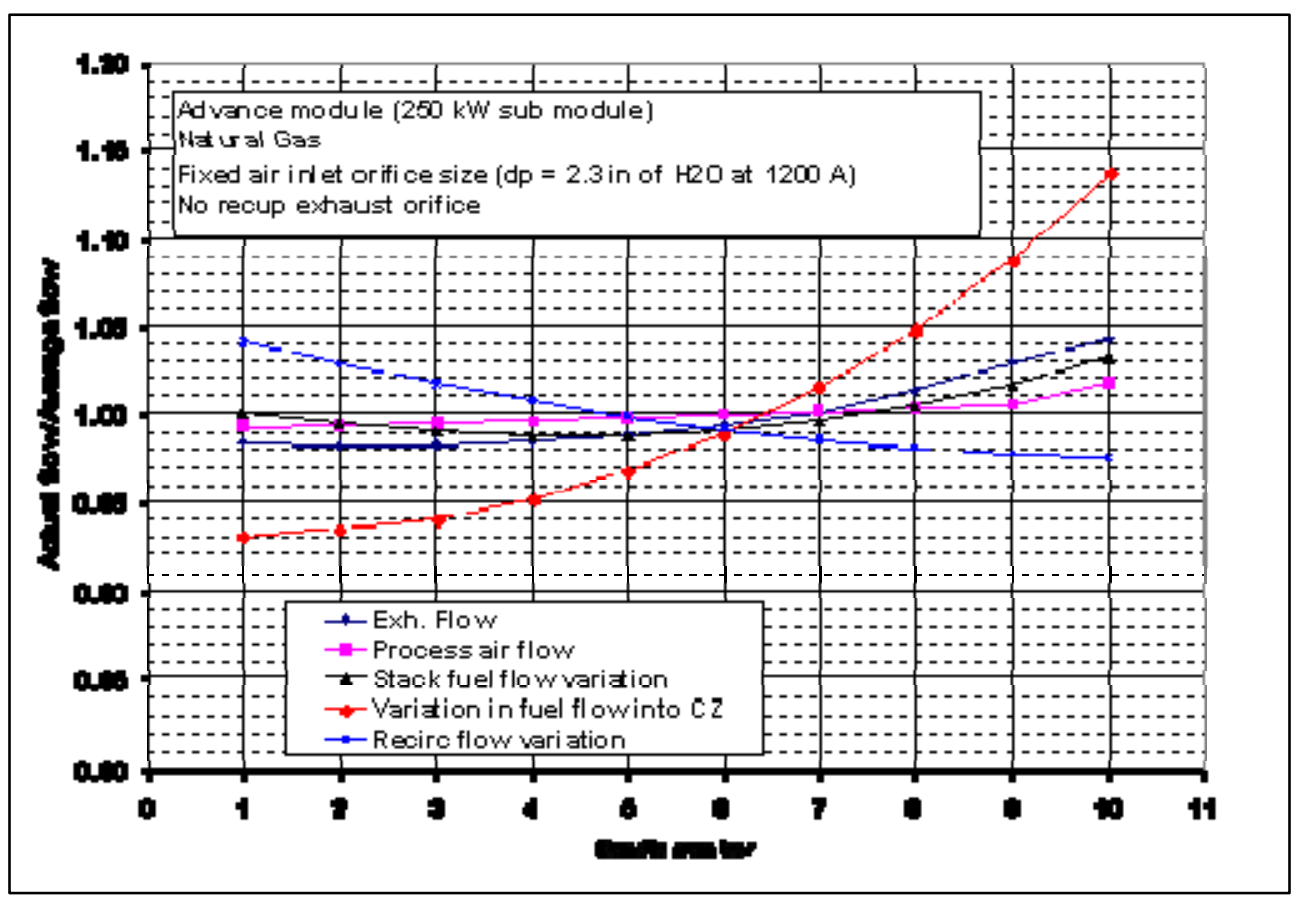

Figure 1.5 - Flow Distribution for the Natural Gas Case $(I=1432 \mathrm{~A}$, air inlet orifice $\mathrm{dP}=2.3$ in of $\mathrm{H} 2 \mathrm{O})$

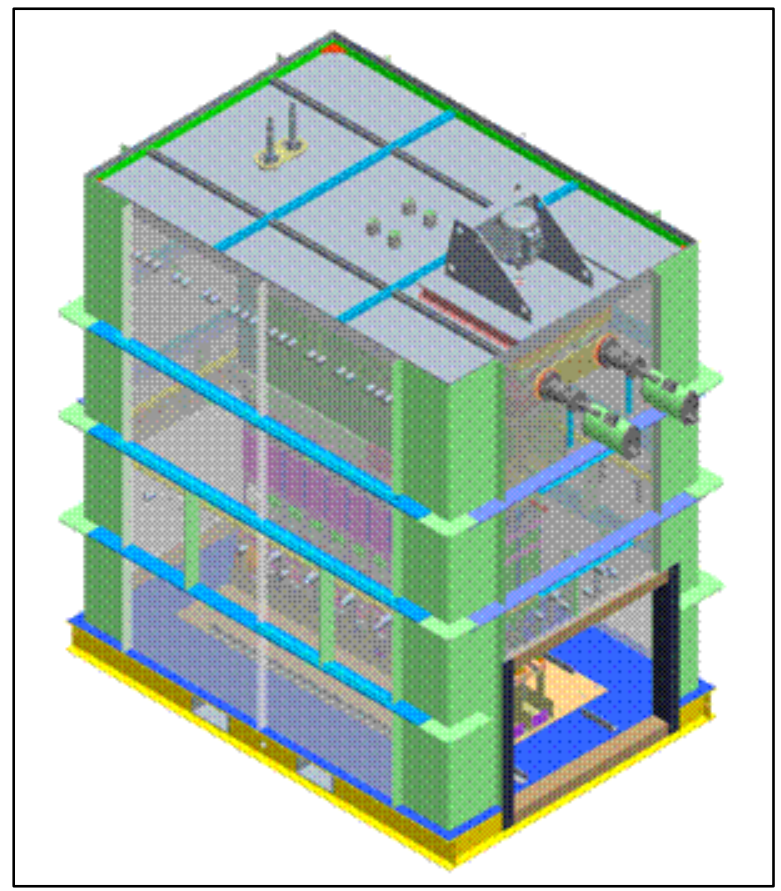

Figure 1.6 - 95 kWe - 285 kWe Module with Internal Recirculation Loop 


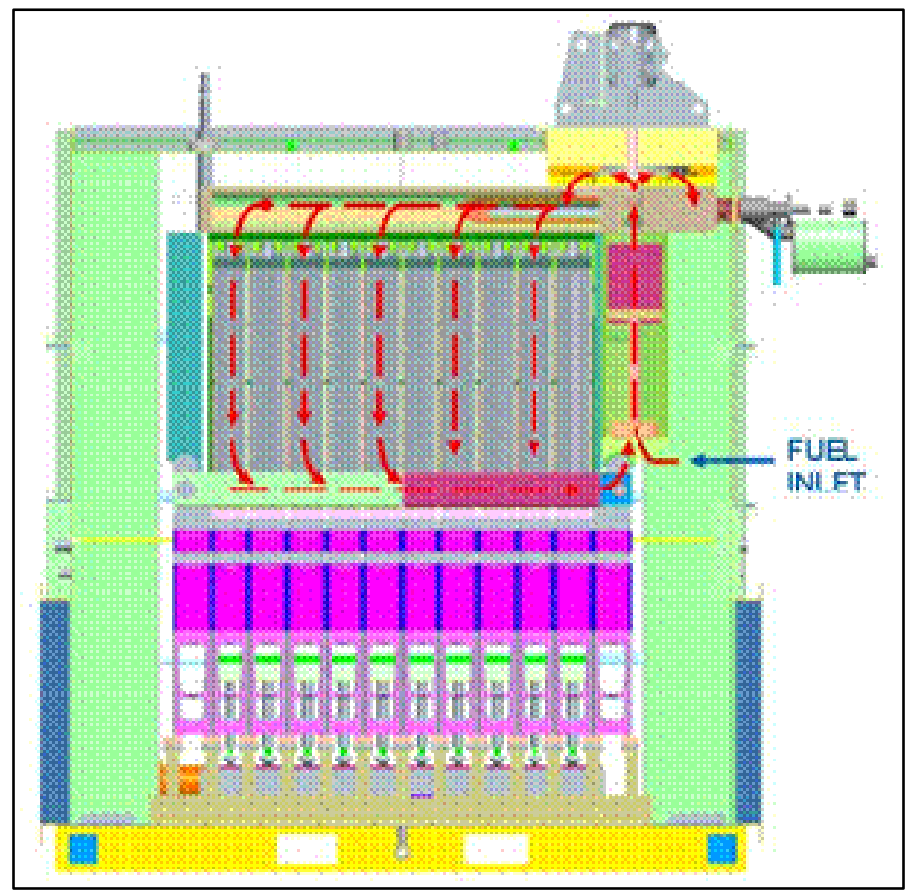

Figure 1.7 - Section View of Internal Recirculation Loop

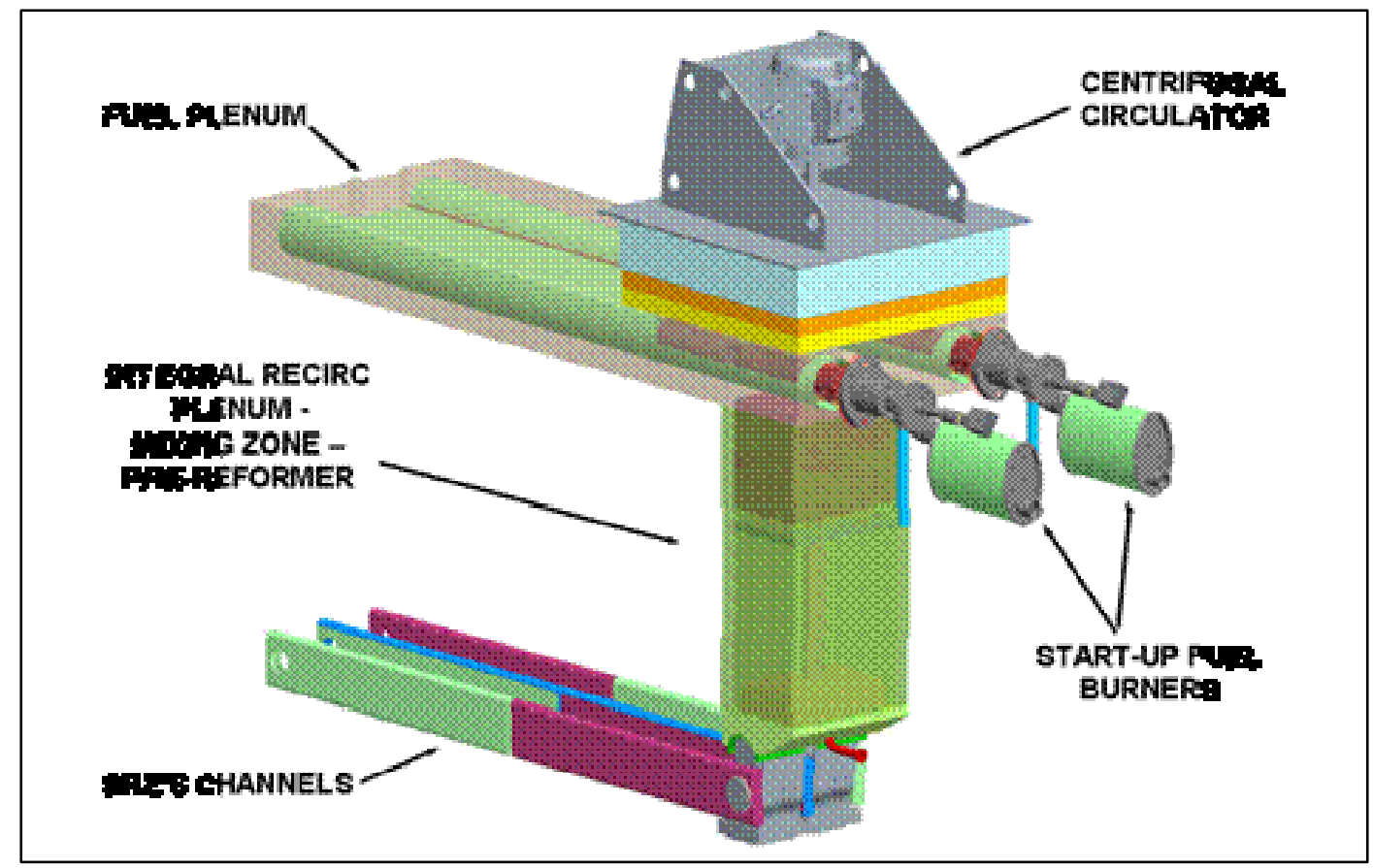

Figure 1.8 - 95 kWe-class Test Article Internal Recirculation Loop 


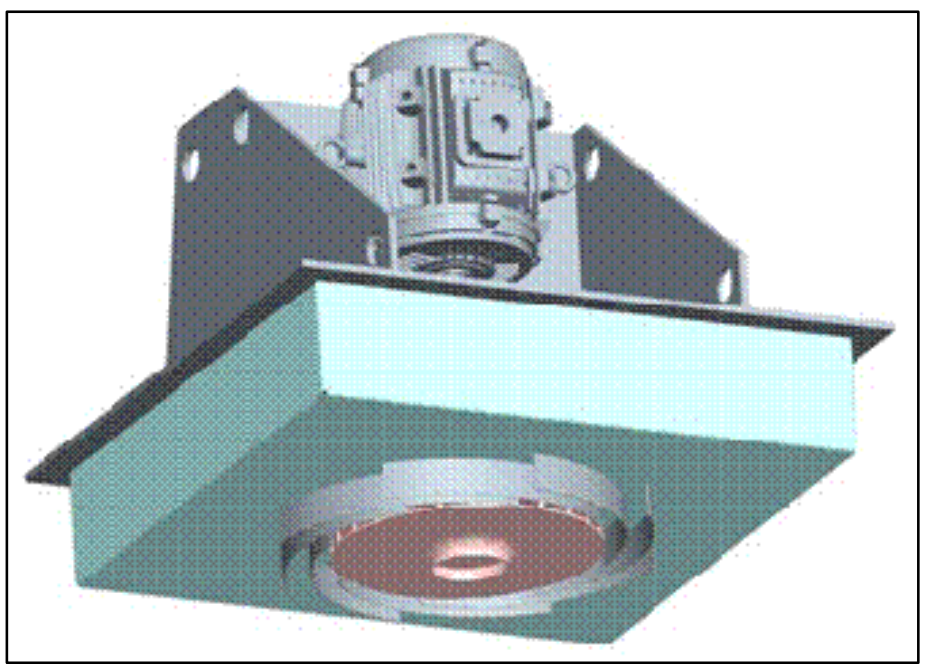

Figure 1.9 - Anode Gas Circulator

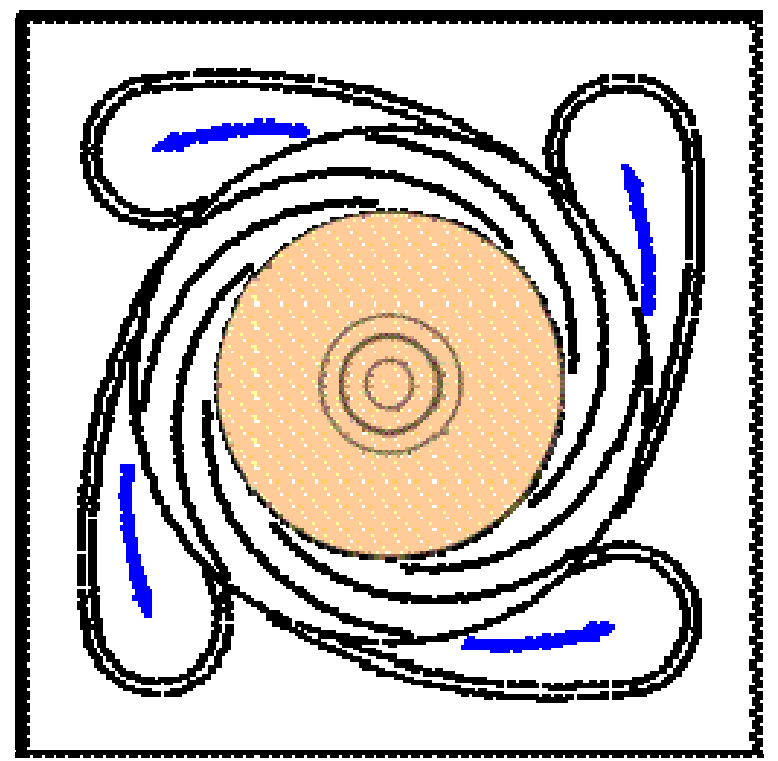

Figure 1.10 - Circulator Lower Volute Chamber 

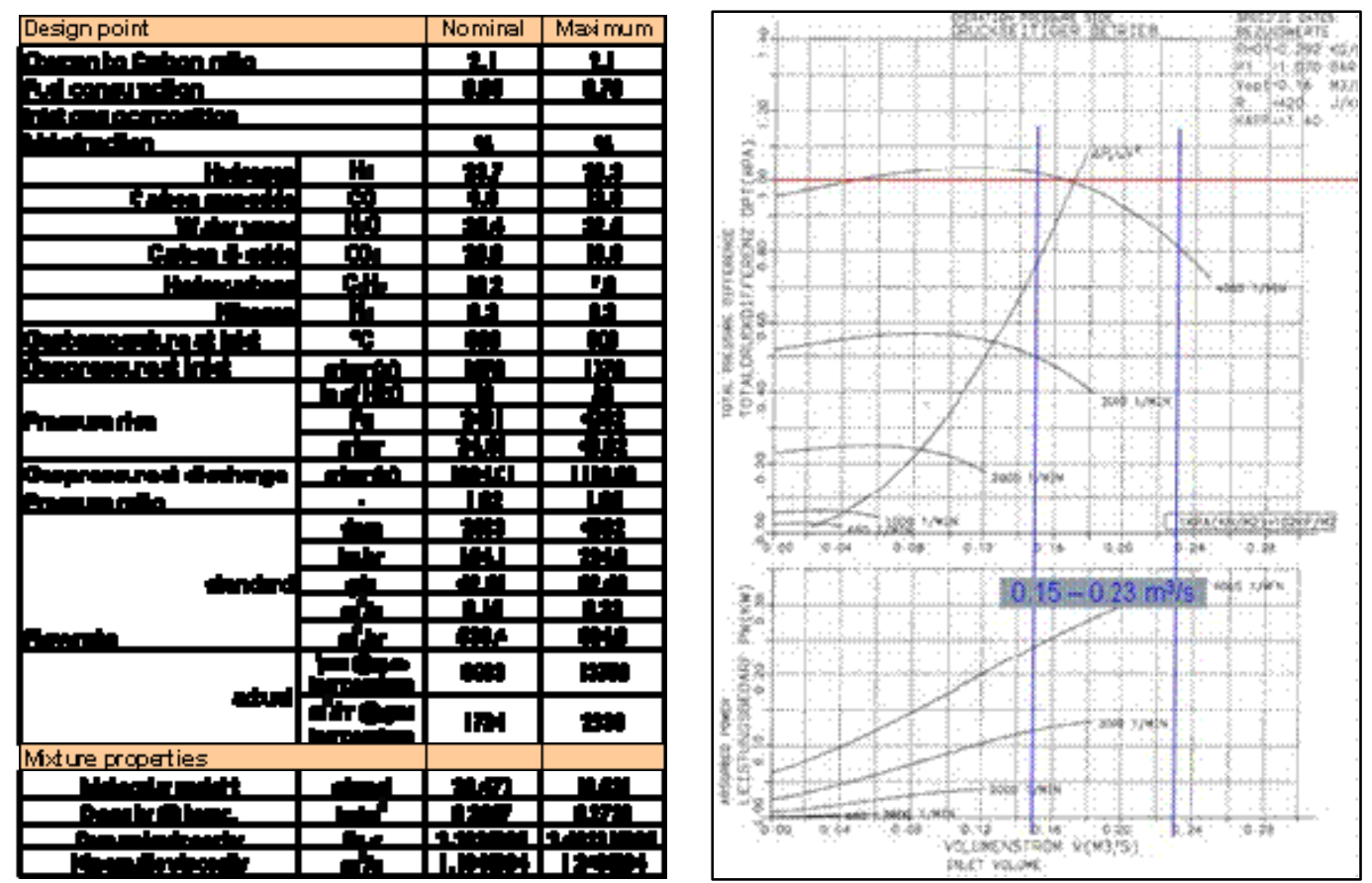

Figure 1.11 - Circulator Specifications and Performance Curves

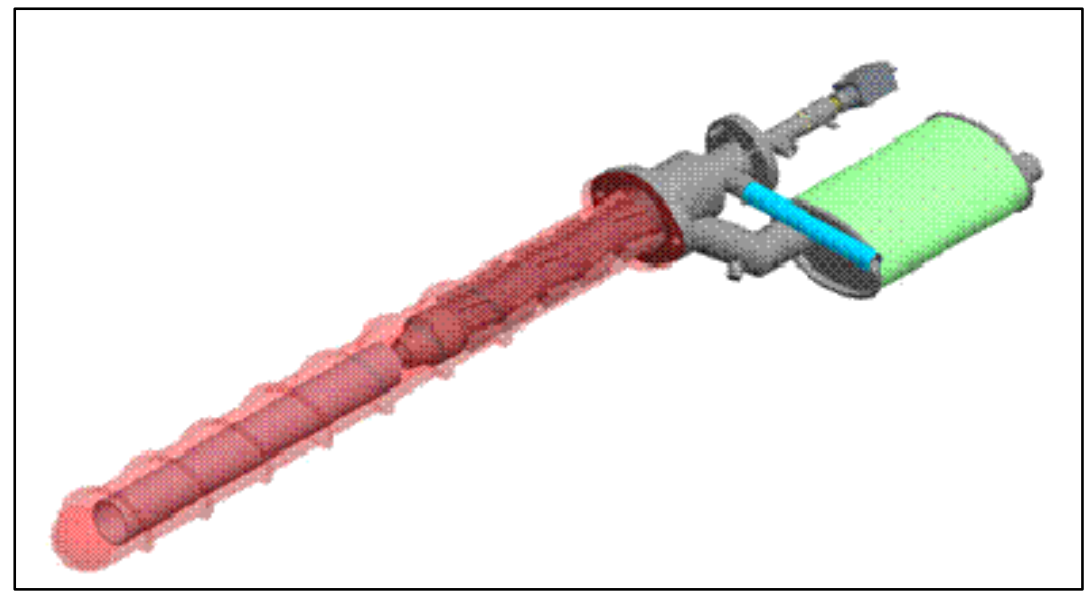

Figure 1.12 - Start-up Gas Fired Burner 


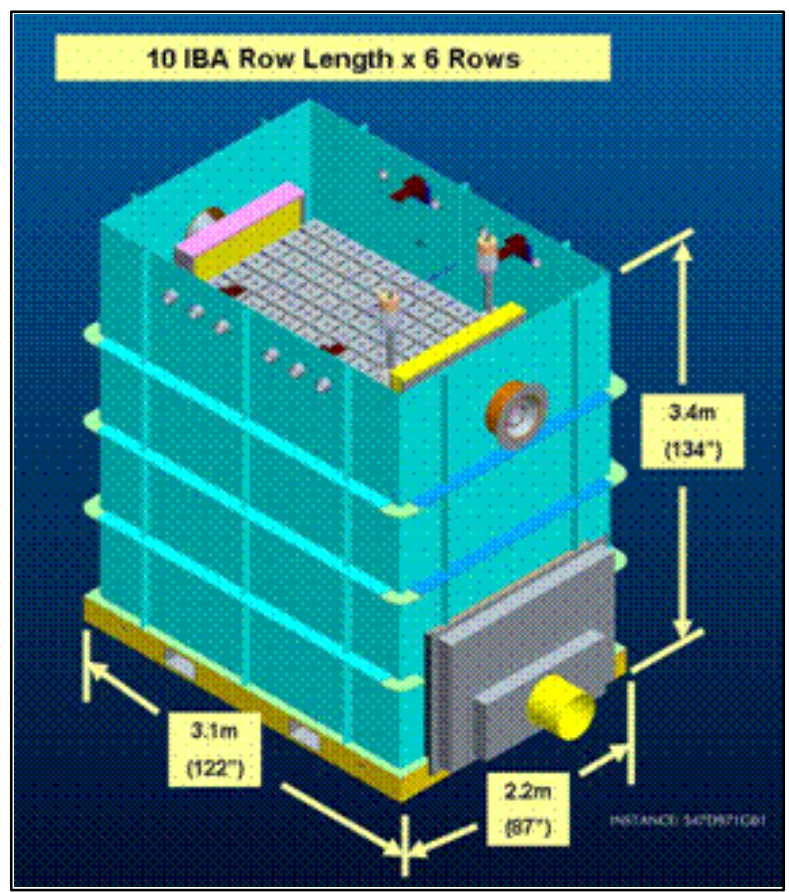

Figure 1.13 - Original Advanced Module Design

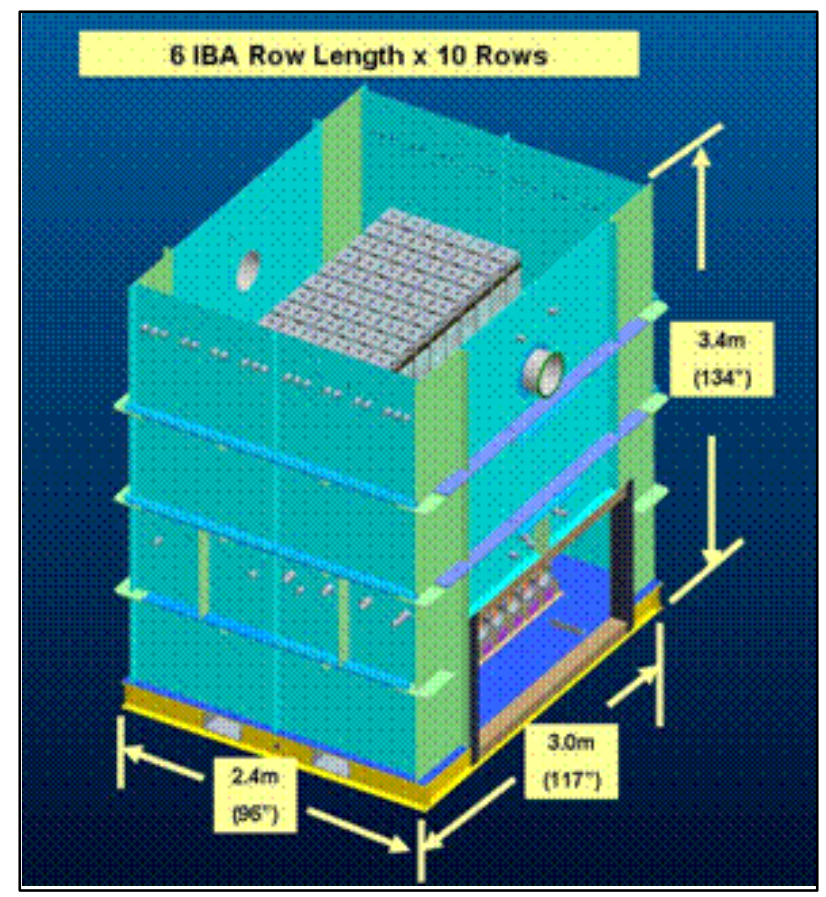

Figure 1.14 - Proposed Design for the 285 kWe-Class Advanced Module 


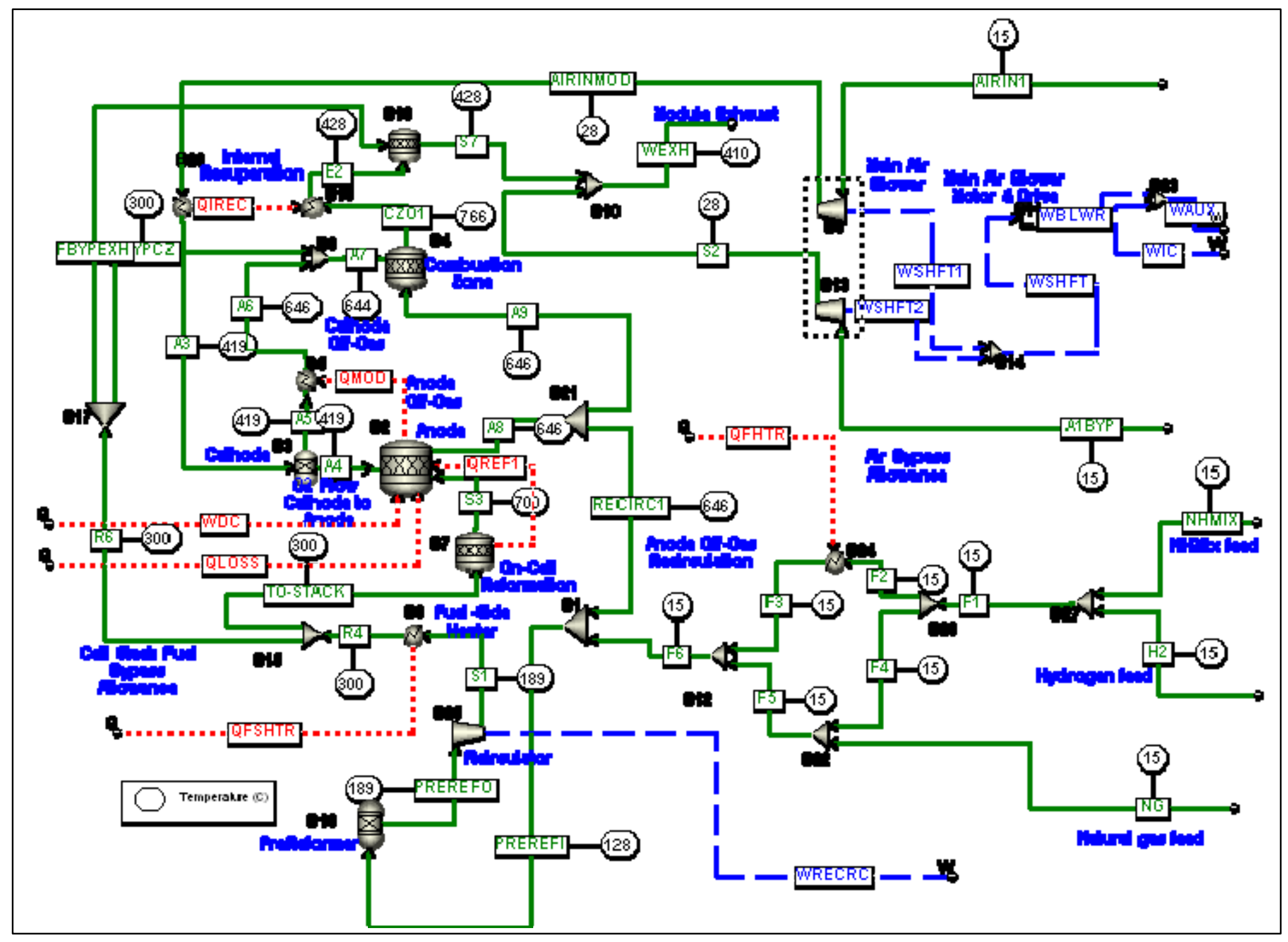

Figure 1.15 - Temperature Map for the $95 \mathrm{kWe}$-Class Test Article (Syngas Fuel, I = 834A) 


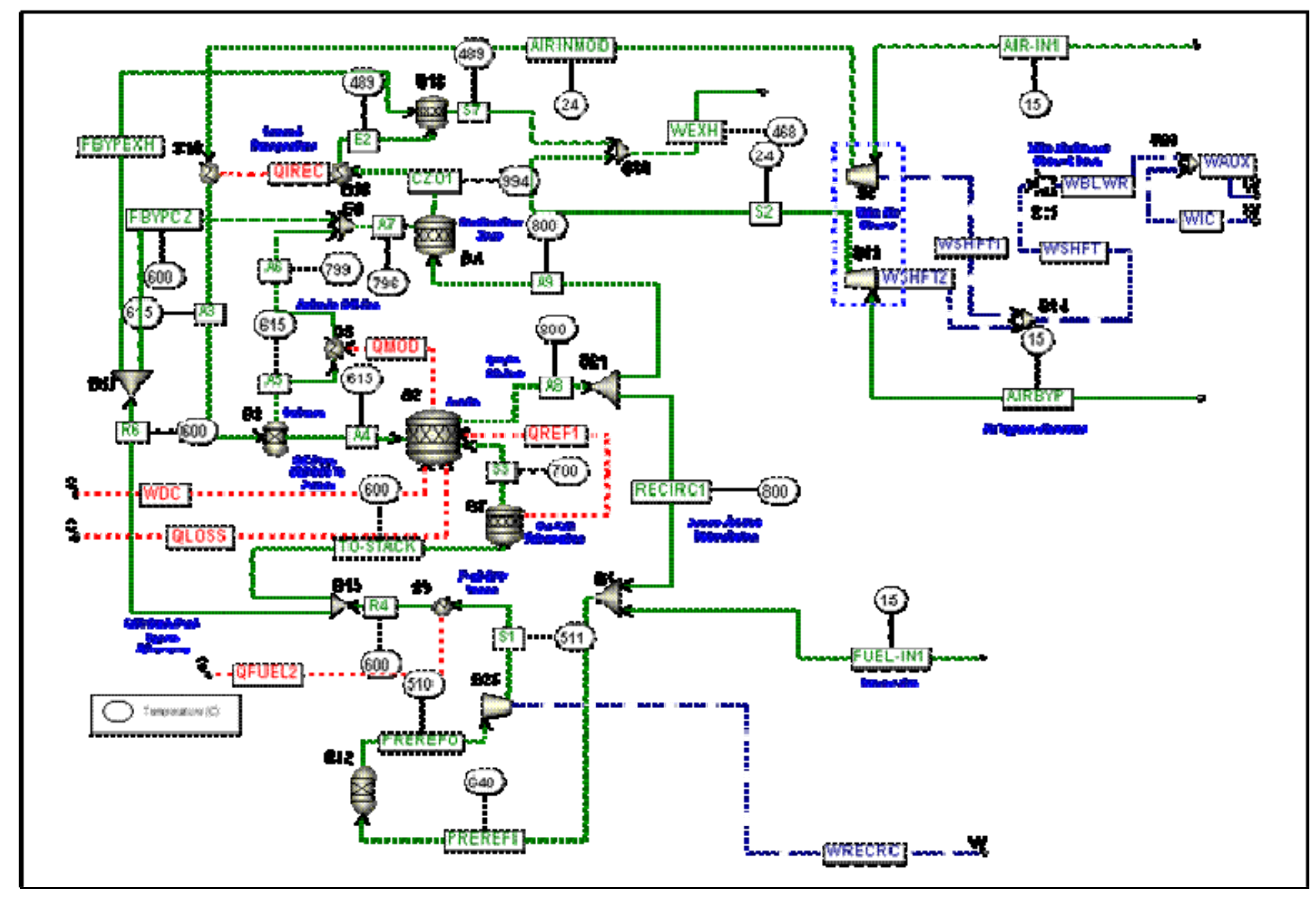

Figure 1.16 - Temperature Map for the $95 \mathrm{kWe}$-Class Test Article (Natural Gas Fuel, I = 834A) 


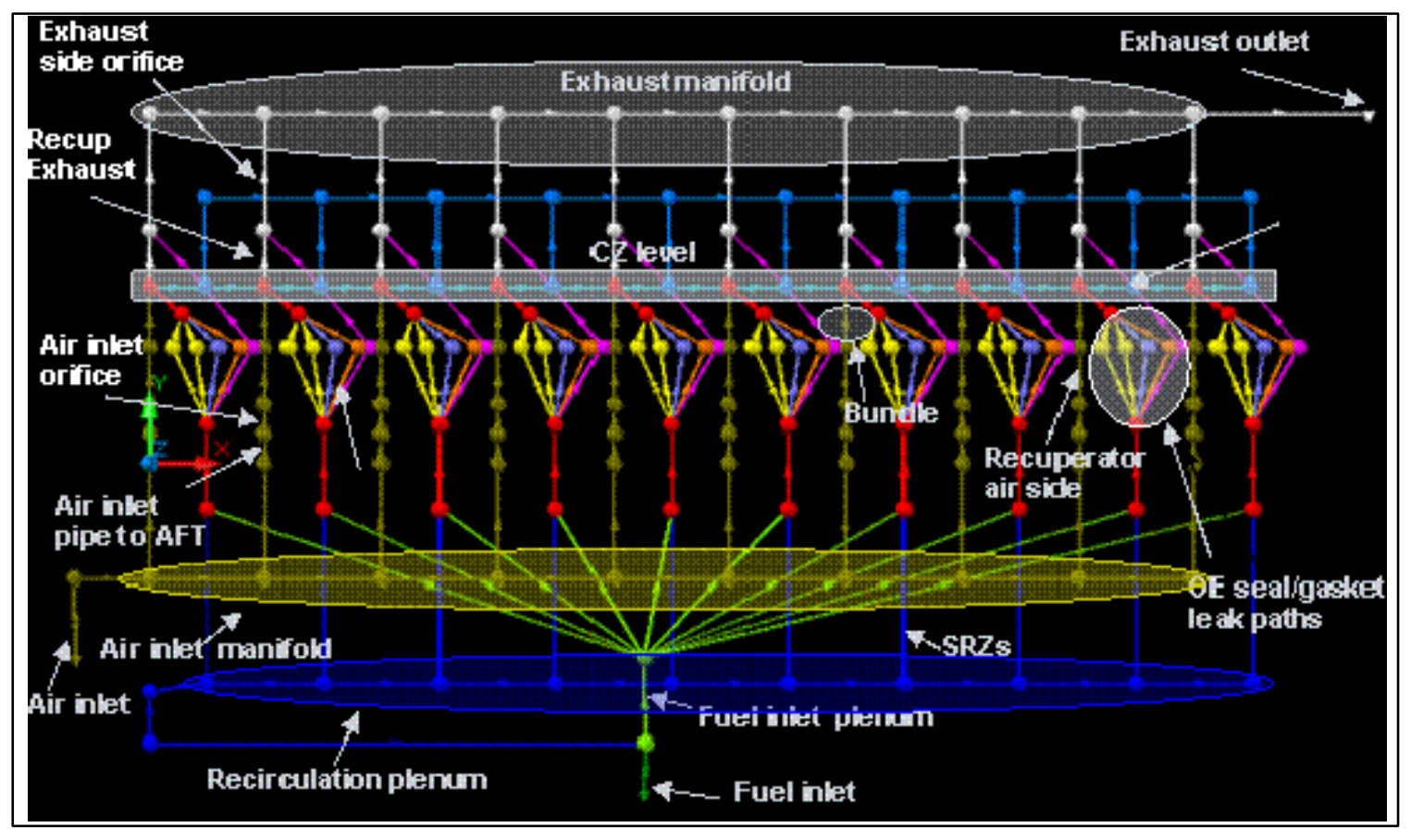

Figure 1.18 - SINDA/FLUINT Flow Network of a Ten Bundle - Bundle Row

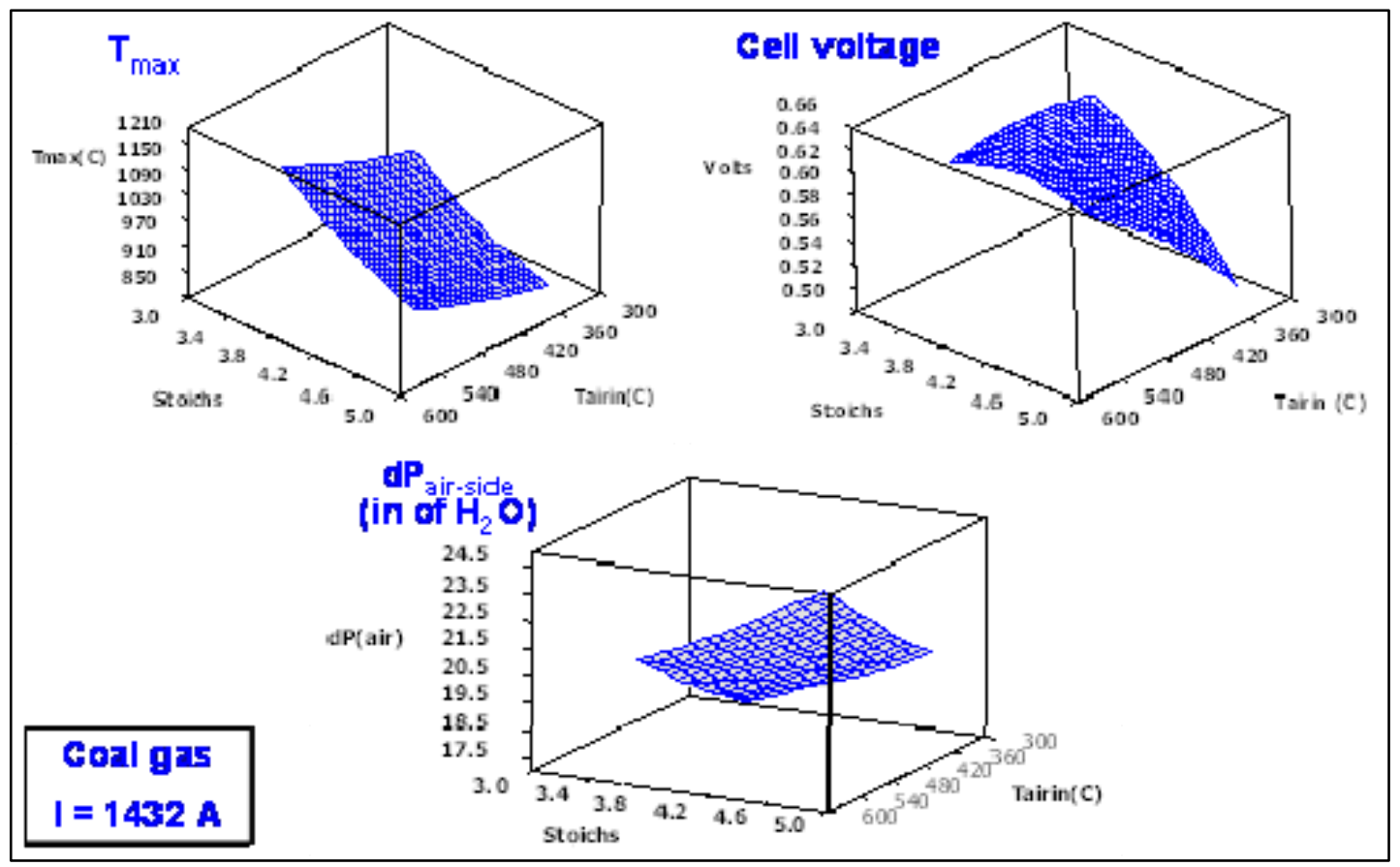

Figure 1.19 - Fluent Generated Maps - Multivariate Regression Model 


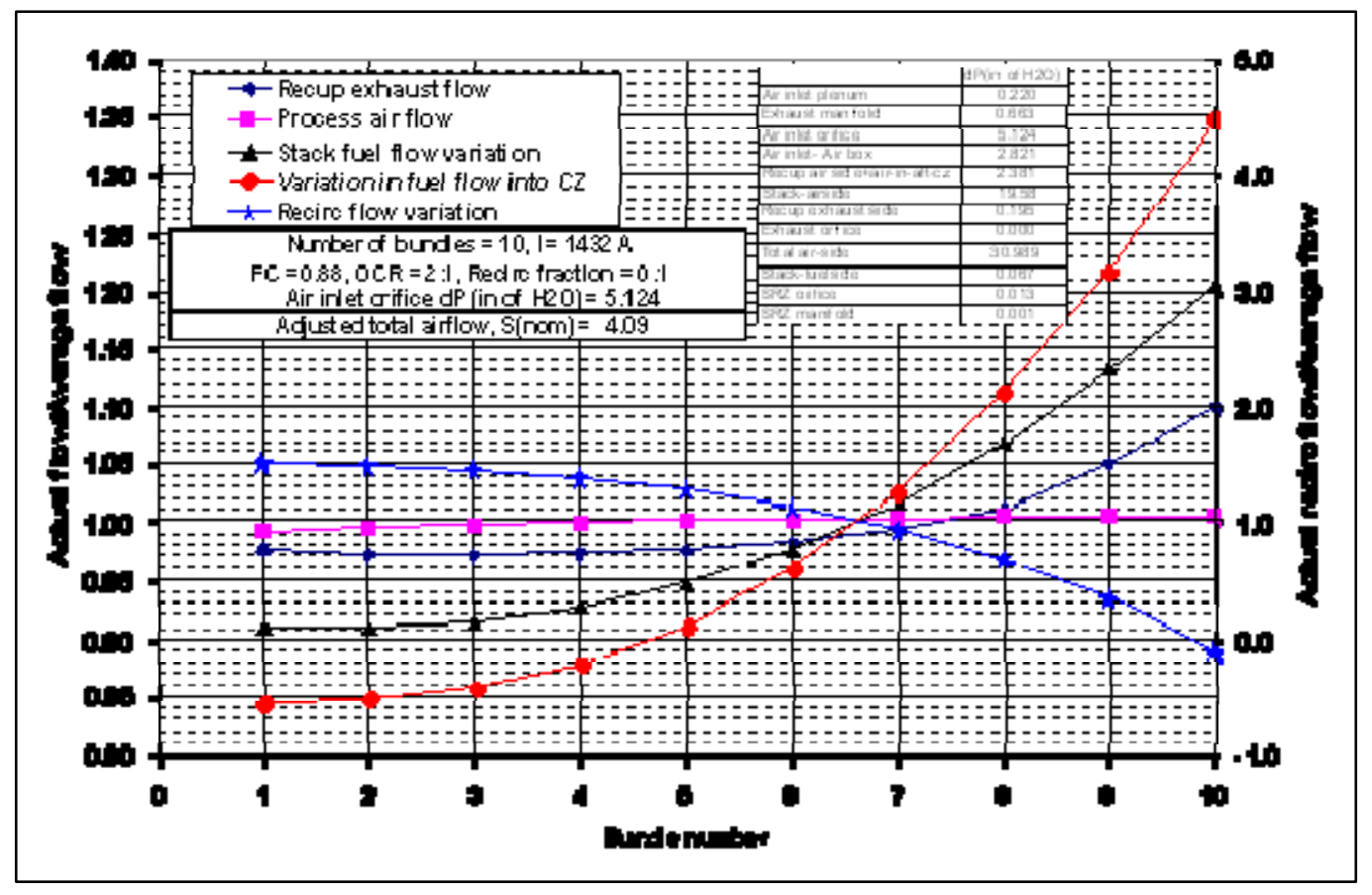

Figure 1.20 - Flow Distribution for a Ten Bundle Row (Syngas Fuel, I = $1432 \mathrm{~A}$, air inlet orifice dP $\approx 5$ in of $\mathrm{H}_{2} \mathrm{O}$ )

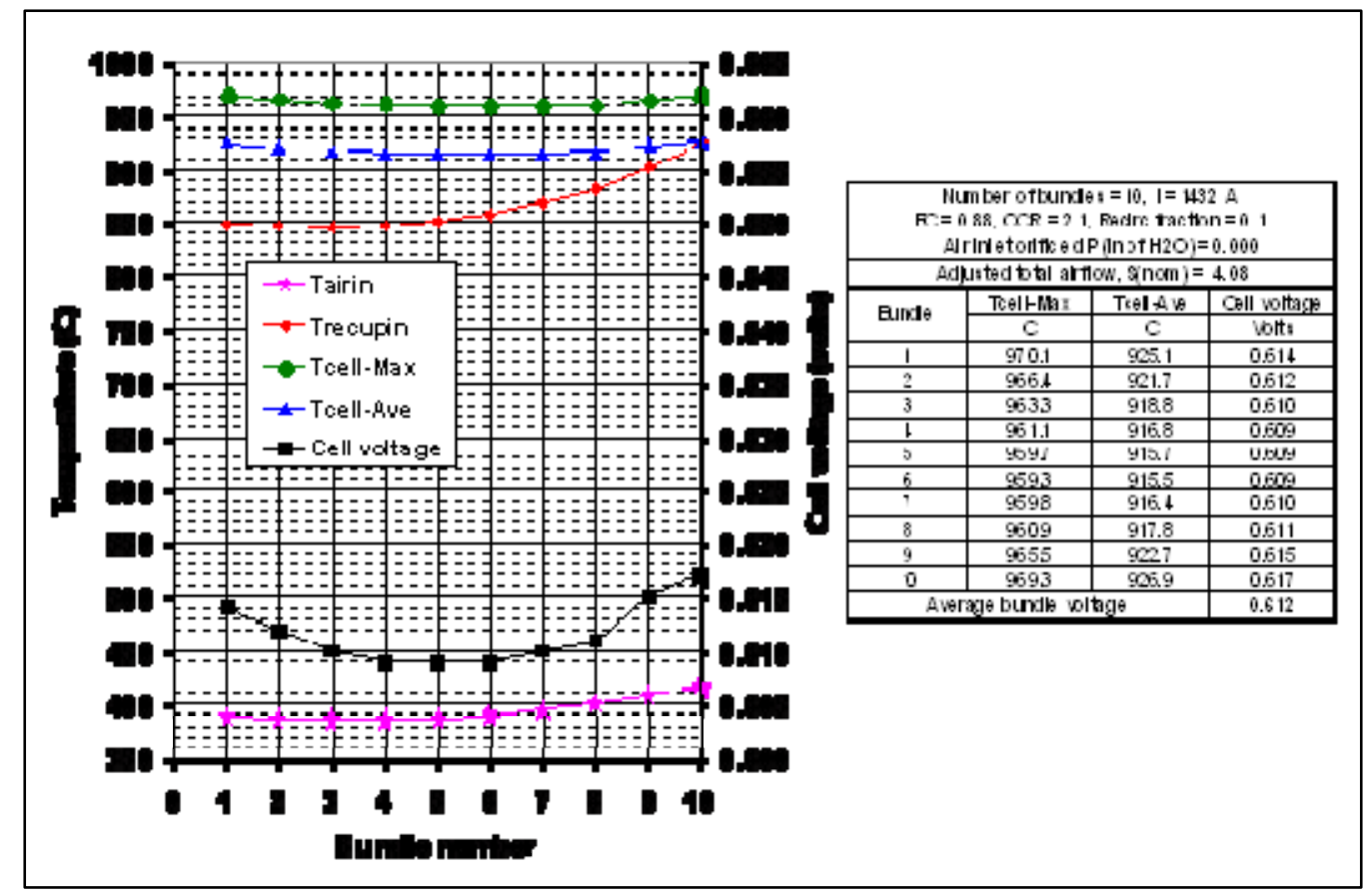

Figure 1.21 - Temperature Distribution for a Ten Bundle Row (Syngas Fuel, I = $1432 \mathrm{~A}$, air inlet orifice dP $\approx 5$ in of $\mathrm{H}_{2} \mathrm{O}$ ) 


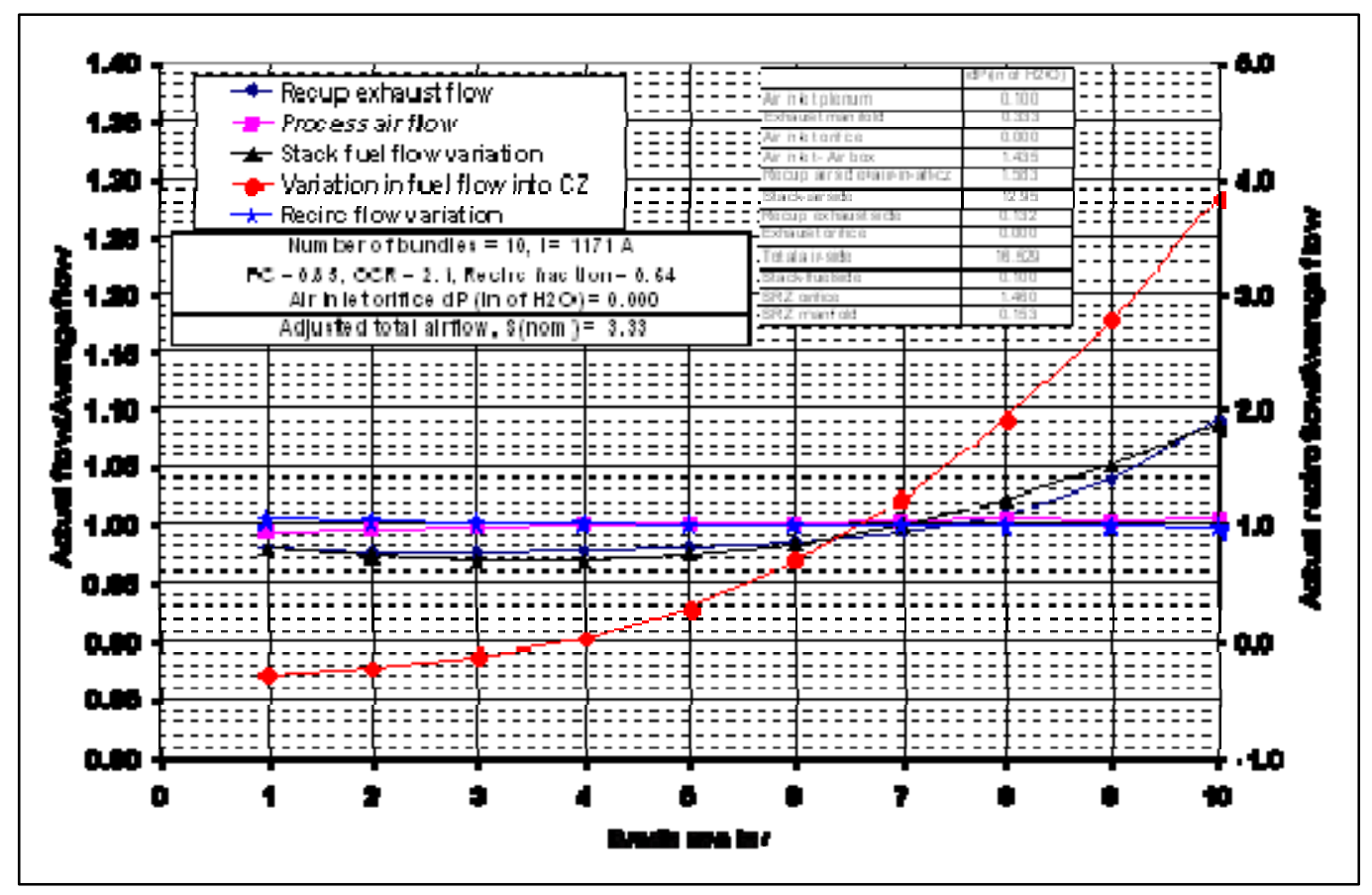

Figure 1.22 - Flow Distribution for a Ten Bundle Row (Natural Gas Fuel, I = $1171 \mathrm{~A}$ )

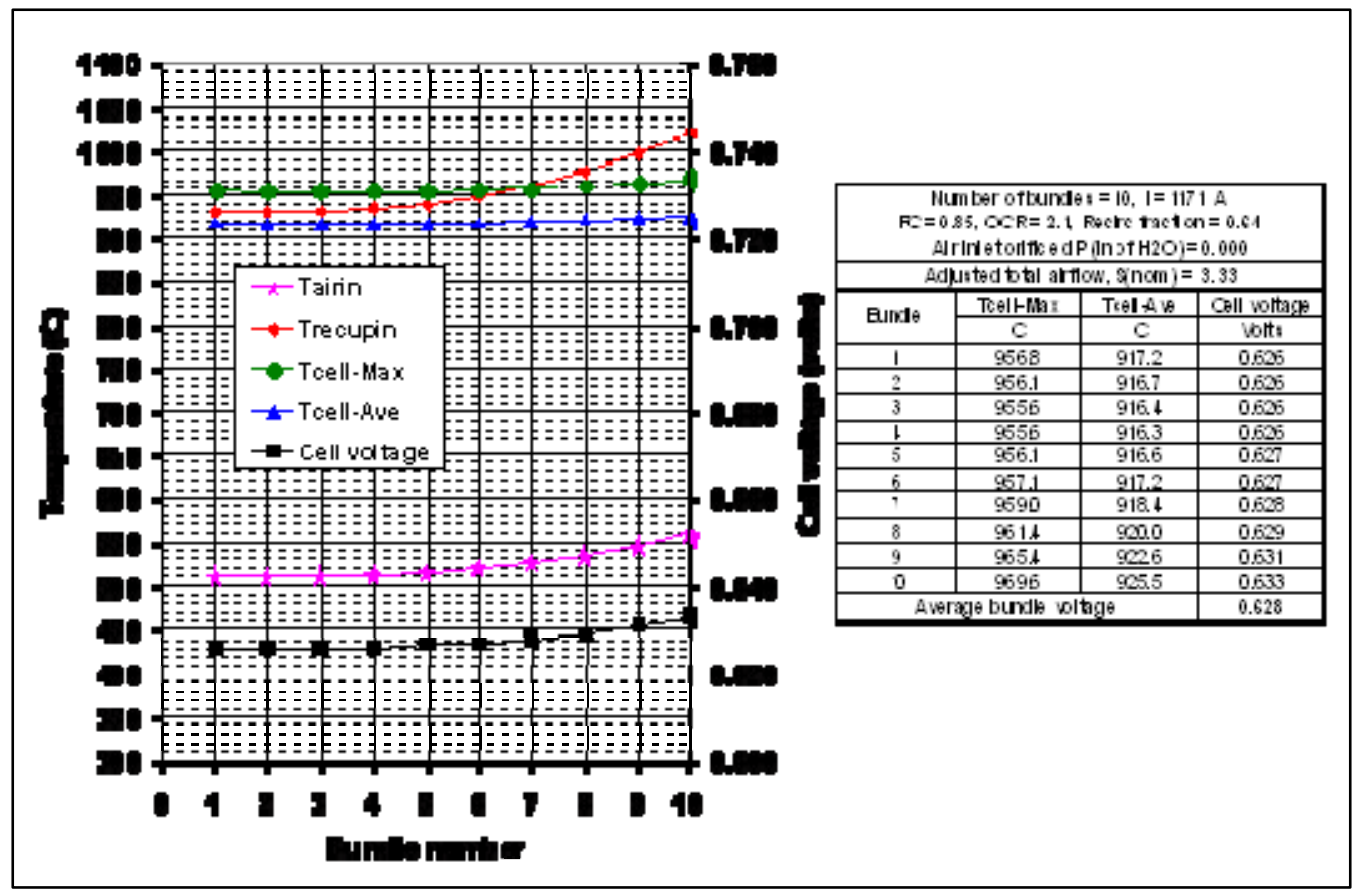

Figure 1.23 - Flow Distribution for a Ten Bundle Row (Natural Gas Fuel, I = 1432 A) 


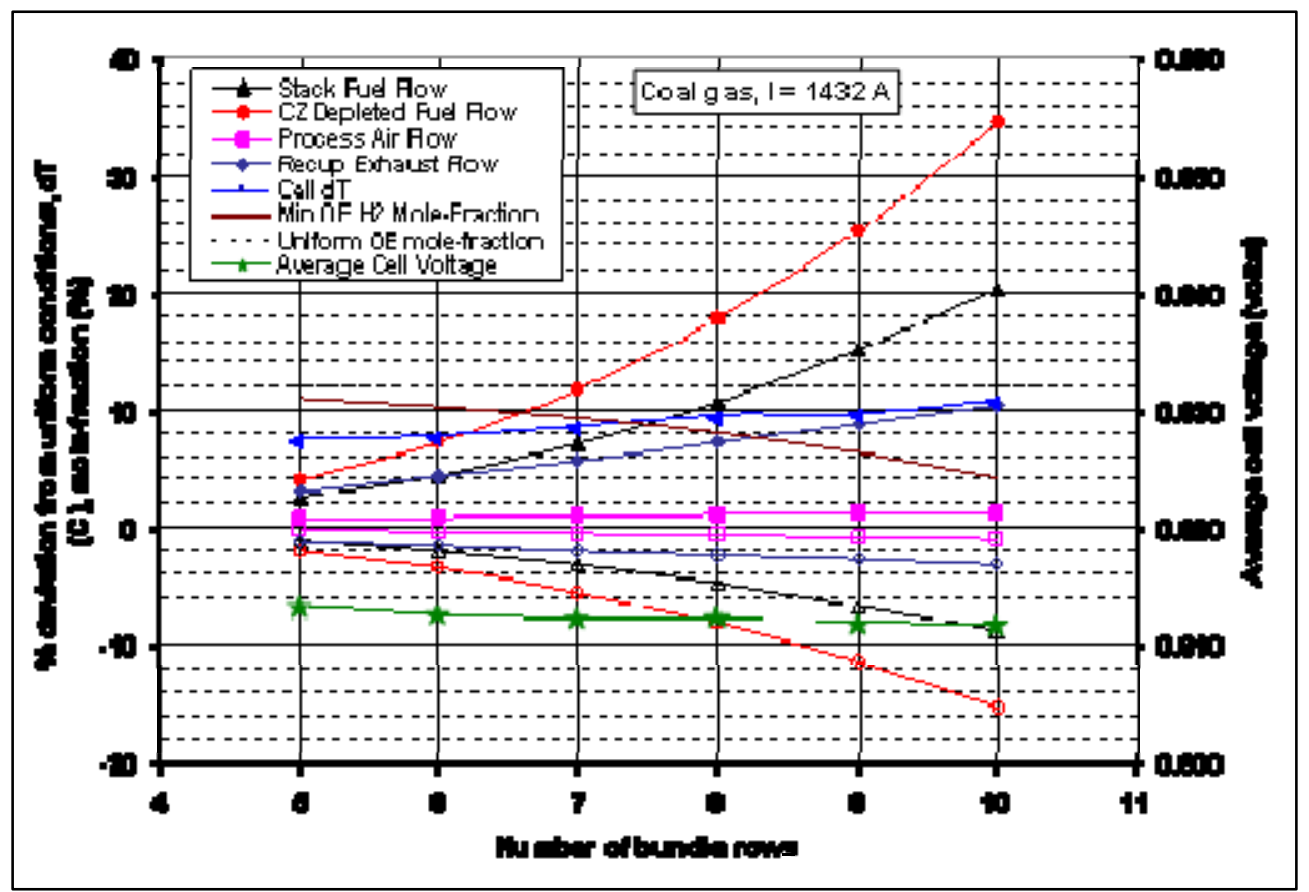

Figure 1.24 - Flow Maldistribution Variation with the Number of Bundles in a Bundle Row

(Syngas Fuel, I = 1432 A)

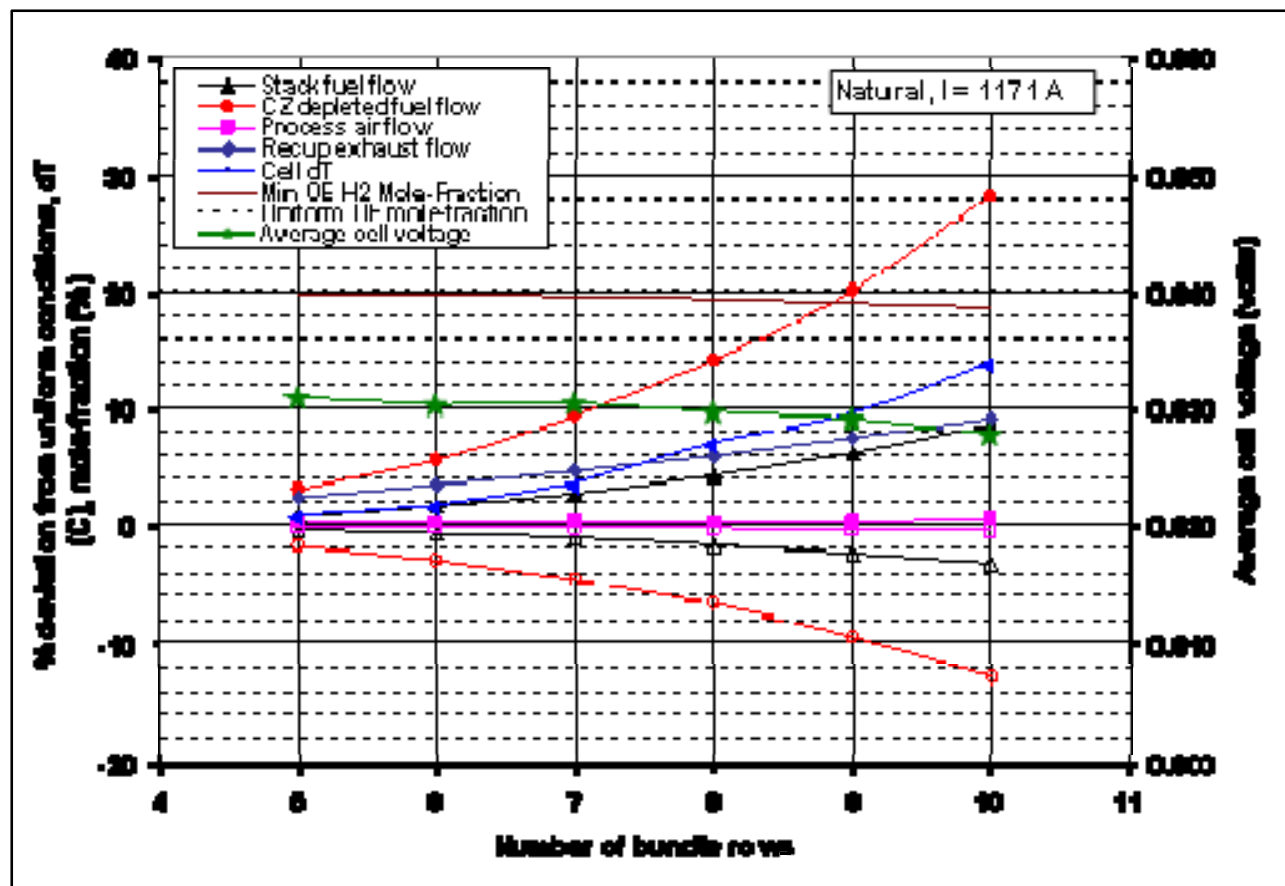

Figure 1.25 - - Flow Maldistribution Variation with the Number of Bundles in a Bundle Row

(Natural Gas Fuel, I = 1171 A) 


\begin{tabular}{|l|c|}
\hline \multirow{2}{*}{ Component } & $\begin{array}{l}\text { Resistance } \\
\text { Index }\end{array}$ \\
\cline { 2 - 2 } & $\Omega$-cm² \\
\hline Cell to Cell & 0.028 \\
\hline Bundle to Bundle & 0.048 \\
\hline Row to Row & 0.096 \\
\hline Bundle to Bus Bar & 0.048 \\
\hline Bus Bar & 0.498 \\
\hline
\end{tabular}

Table 1.1 - Component Resistance Indices 


\begin{tabular}{|c|c|c|c|c|c|}
\hline Current & isity & $\mathrm{J}\left(\mathrm{mA} / \mathrm{cm}^{2}\right)$ & 150 & 320 & 550 \\
\hline Cell C & & A & 391 & 834 & 1433 \\
\hline & Stoichs & & 5.97 & 4.66 & 3.94 \\
\hline Module Air flow & Mass flow & $\mathrm{kg} / \mathrm{s}$ & 0.424 & 0.706 & 1.026 \\
\hline & Vol. flow & slpm & 19852 & 33050.2 & 48027.1 \\
\hline & $\mathrm{H} 2$ & slpm & 1267.0 & 2612.1 & 4426 \\
\hline Fuel flow & NG & slpm & 86.2 & 173.6 & 293.7 \\
\hline & NHMIX & slpm & 30.2 & 61.8 & 105.3 \\
\hline Recirculator flow & Vol. flow & slpm & 1607.5 & 3296.7 & 5584 \\
\hline & & Volte & D.74 & 0.712 & DEl3 \\
\hline & Areten? & C & E.5.8 & 5 & 9.25 \\
\hline ehro & & F & $\operatorname{mpn}$ & $\ln r$ & 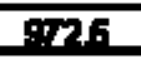 \\
\hline & & C. & 75 & 겨요 & 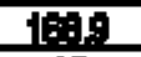 \\
\hline Proer- endrald & & $\mathbf{c}$ & 15 & 16 & 15 \\
\hline Prot- & Pl & C & 718 & 78 & 5.1 \\
\hline & & a & $27 x^{2}$ & $\operatorname{lng}$ & $\sin 7$ \\
\hline & יde & C & 15 & 16 & 16 \\
\hline & in-lnendion & C & Bis.6 & BNB & 715 \\
\hline$=0100$ & & C & $17: 1$ & 179 & 1412 \\
\hline & & C & 189.49 & 19:A & 7.072 \\
\hline & & C & m & $\mathrm{m}$ & 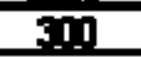 \\
\hline Exhor the & & c & Oita & Plss & 716 \\
\hline Exilation & & C & $7 !$ & 749 & F! \\
\hline Intip & 2. & C & $2 ! 1$ & $28 A$ & 619? \\
\hline inevger ane & & & DE: & $0 \times 2$ & D.4 \\
\hline & Finrytor & hrtan: & 789 & 179 & 19.17 \\
\hline & R! & hertinter & 0.72 & $1 . x$ & 172 \\
\hline Prearura dropa & P蒠=2 & hritust:er & 18 & $4 \pi$ & 74 \\
\hline & EDP & hremer.: & 18 & 46 & 98 \\
\hline & $|r| r \mid$ & Leti.: & 1185 & 795 & 379 \\
\hline & & MW & 67 & 19.2 & 142 \\
\hline $1=$ & IS & Mith & 250 & 23 & 23 \\
\hline ruberate & $\mathrm{PC}$ & Mill & 17.19 & 18.14 & 787 \\
\hline & Totnl & Whe & 2.122 & 3900 & 727 \\
\hline & Fuel & $\mathbf{k W}$ & 330.9 & 6792 & 1150.6 \\
\hline Fnergy flawe & Cell & kWe & 148.9 & 285 & 421.5 \\
\hline & Stack DC & kWe & 147.9 & 280.3 & 407.6 \\
\hline & Net $A C$ & kWe & 127.8 & 242.0 & 3365 \\
\hline & Cell & $\%$ & 45.0 & 42.0 & 36.6 \\
\hline Efficiencies & Stack DC & $\%$ & 44.7 & 41.3 & 35.4 \\
\hline & Net AC & $\%$ & 38.6 & 35.6 & 29.2 \\
\hline
\end{tabular}

Table 1.2 - 250 kWe-Class System Performance for Syngas Fuel 


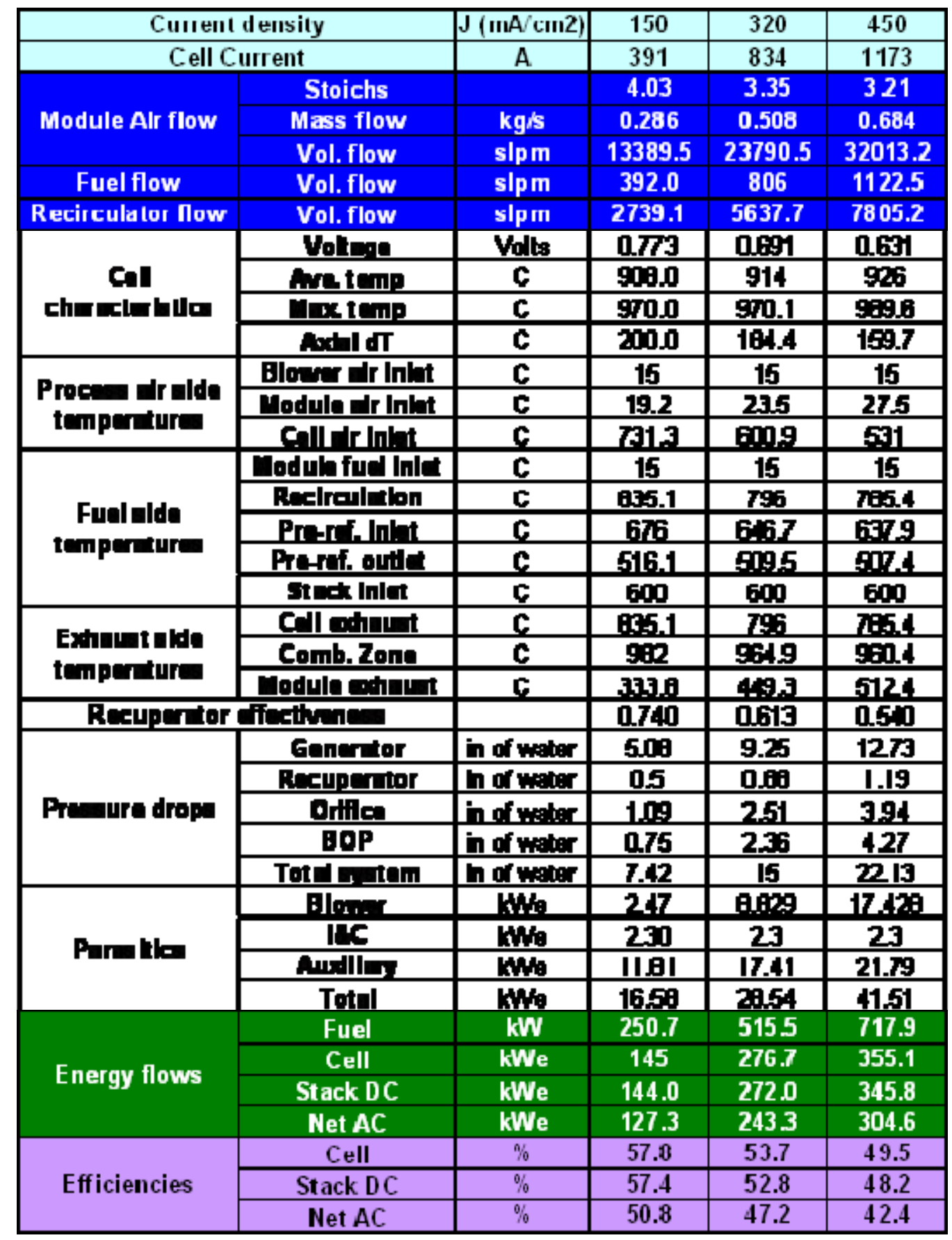

Table 1.3 - 250 kWe-Class System Performance for Natural Gas 


\begin{tabular}{|c|c|c|c|}
\hline & & $95 \mathrm{kWe}$ & $285 \mathrm{kWe}$ \\
\hline Cell Geometry & & \multicolumn{2}{|c|}{ Delta 8} \\
\hline \multirow{3}{*}{ Cell material set } & & \multicolumn{2}{|c|}{ AE - WPC3 } \\
\hline & & \multicolumn{2}{|c|}{ Electrolyte - ScSZ } \\
\hline & & \multicolumn{2}{|c|}{ FE - NiScSz } \\
\hline Cell class & & \multicolumn{2}{|c|}{ POCD8R1 class } \\
\hline Cell active length & $\mathrm{m}$ & \multicolumn{2}{|c|}{1} \\
\hline Cell active area & sq. $\mathrm{m}$ & \multicolumn{2}{|c|}{2606} \\
\hline Number of cells & & 160 & 480 \\
\hline OCR & & \multicolumn{2}{|c|}{2.1} \\
\hline Air bypass allowance & $\%$ & \multicolumn{2}{|c|}{5} \\
\hline Fuel bypass allowance & $\%$ & 5 & 1.5 \\
\hline Cell peak temperature & C & \multicolumn{2}{|c|}{970} \\
\hline Blower air inlet temperature & C & \multicolumn{2}{|c|}{15} \\
\hline Fuel inlet temperature & C & \multicolumn{2}{|c|}{15} \\
\hline Air blower efficiency & $\%$ & \multicolumn{2}{|c|}{35} \\
\hline Recirculator blower efficiency & & \multicolumn{2}{|c|}{ Not modeled } \\
\hline Inverter efficiency & & \multicolumn{2}{|c|}{ Based on a PCS model } \\
\hline I \& C allowance & $\mathrm{kWe}$ & 1.0 & 2.3 \\
\hline Module heat loss & kW & 7.0 & 15.0 \\
\hline
\end{tabular}

Table 1.4 - Analysis Assumptions Common to both Natural Gas and Syngas Fuels 


\begin{tabular}{|l|l|l|l|}
\hline \multicolumn{2}{|l|}{} & Natural gas & \multicolumn{1}{c|}{ Syngas } \\
\hline Fuel consumption & 0.85 & 0.88 \\
\hline $\begin{array}{l}\text { Fuel composition } \\
\text { entering module } \\
\text { Mole fractions }\end{array}$ & Pittsburgh NG & $\begin{array}{c}\text { Mixture of } \mathrm{H}_{2}, \\
\text { Pittsburgh NG, } \\
\text { NHMIX to simulate } \\
\text { chosen coal gas }\end{array}$ \\
\hline $\mathbf{H}_{\mathbf{2}}$ & $\%$ & - & 91.85 \\
\hline $\mathbf{C O}$ & $\%$ & - & - \\
\hline $\mathbf{H}_{\mathbf{2}} \mathbf{O}$ & $\%$ & - & - \\
\hline $\mathbf{C O}_{\mathbf{2}}$ & $\%$ & - & - \\
\hline $\mathbf{C H}_{\mathbf{4}}$ & $\%$ & 94.41 & 5.78 \\
\hline $\mathbf{C}_{\mathbf{2}} \mathbf{H}_{\mathbf{6}}$ & $\%$ & 3.08 & 0.188 \\
\hline $\mathbf{C}_{\mathbf{3}} \mathbf{H}_{\mathbf{8}}$ & $\%$ & 0.56 & 0.034 \\
\hline $\mathbf{C}_{\mathbf{4}} \mathbf{H}_{10}$ & $\%$ & 0.19 & 0.108 \\
\hline $\mathbf{N}_{\mathbf{2}}$ & & 4.28 & 2.04 \\
\hline $\mathbf{H}_{\mathbf{2}}$ equivalent & $\mathrm{kJ} / \mathrm{kg}$ & 49453 & 1.06 \\
\hline $\mathbf{L H V}$ & $\mathrm{C}$ & 600 & 61686 \\
\hline $\begin{array}{l}\text { Stack fuel inlet } \\
\text { temperature }\end{array}$ & & & 300 \\
\hline
\end{tabular}

Table 1.5 - Analysis Assumptions Specific to the Fuel Used 


\begin{tabular}{|c|c|c|c|c|c|c|c|c|c|c|c|c|c|c|}
\hline \multirow{3}{*}{\multicolumn{2}{|c|}{ 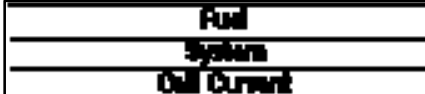 }} & & \multicolumn{6}{|c|}{ Ex? } & \multicolumn{6}{|c|}{ 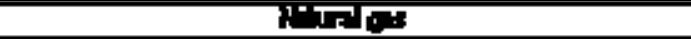 } \\
\hline & & & \multirow{2}{*}{\multicolumn{3}{|c|}{ 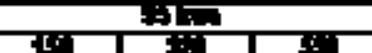 }} & \multirow{2}{*}{\multicolumn{3}{|c|}{ 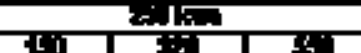 }} & \multirow{2}{*}{\multicolumn{3}{|c|}{ Fin: }} & \multirow{2}{*}{\multicolumn{2}{|c|}{ (2) }} & \multirow{3}{*}{ Lis } \\
\hline & & $\mathbf{I}$ & & & & [Li] & & & Fi & & TFA & & & \\
\hline $6=1$ & ता & $\boldsymbol{L}$ & FI & 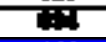 & $\mathrm{THA}$ & FI & Tir & $\mathrm{FHA}$ & FFII & & Tra & Fi & Tin & \\
\hline \multirow{3}{*}{ Module Bir flow } & Stcichs & & 6.00 & 469 & 4.00 & 5.97 & 4.66 & 394 & 4.09 & 3.41 & 326 & 426 & 3.41 & 3.24 \\
\hline & Massflow & 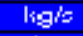 & 0.142 & 0.287 & 0248 & 0.424 & 0.708 & 1.026 & 0.097 & 0.172 & 0.282 & 0.302 & 0.517 & 0.69 \\
\hline & Vol.flow & slpm & 6646.4 & 11095.4 & 162632 & 19852 & 330502 & 48027.1 & 4531.1 & 8070 & 10837.5 & 14147.4 & 24184 & 32272.8 \\
\hline \multirow{4}{*}{ Fual flow } & $\mathrm{H}_{2}$ & $=1 \mathrm{~mm}$ & 4934 & $893 \mathrm{~K}$ & 1.5141 & $1267 \cap$ & 26121 & $\triangle A \sim F$ & & & & & & \\
\hline & NG & sipm & 29.6 & 59.4 & 1005 & 862 & 1736 & 293.7 & 135.5 & 2786 & 388 & 392.0 & 806 & 1122.5 \\
\hline & NHWIX & slpm & 10.4 & 21.1 & 36.0 & 302 & 61.8 & 105.3 & $\cdot$ & & & & & \\
\hline & Wol.flow & slpm & 549.6 & 1126 & 1907.3 & 1607.5 & 3296.7 & 5584 & 949.4 & 1926.5 & 2698.9 & 2816.1 & 5595.7 & 7844.4 \\
\hline & & & art & & & & ort & 100 & $\Rightarrow$ & & 13 & tit & 17 & \\
\hline & 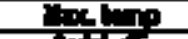 & F & & & & & $\ln 7$ & $7 !$ & & & & & & \\
\hline \multirow{3}{*}{ Proves alride } & 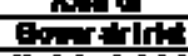 & 15 & 1.1 & & & & $\frac{1.21}{1.2}$ & II & & & & & & \\
\hline & 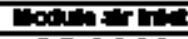 & F. & Fा/ & $\pi$ & $F .1 .1$ & Tाम & $7 n$ & Fil & 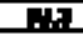 & & $7 \pi$ & 1 & Tix & 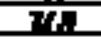 \\
\hline & DIrit & F & 57 & $\$ 2$ & $2 . .99$ & sta & 1.01 & $\ldots 7$ & E.I. & lotit & Ean & & nIK & $f: n^{9}$ \\
\hline \multirow{4}{*}{ frid } & 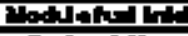 & I & & & & & & II & & & & & & \\
\hline & 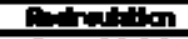 & F. & DII & & mIn & & & 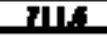 & & & & & & \\
\hline & mentitis & F & INT & & E:29-1 & & It & Eta? & & & & & & \\
\hline & mon & F & $I \%$ & & & & & $7 \%$ & & & & & & \\
\hline \multirow{2}{*}{ Ehoritidn } & oldith & F & DII & I. & rall & 1... & ex:12 & Ills & thin & & 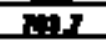 & & & \\
\hline & $\mathbf{m}$ & & ran2 & & & & $7+2$ & & & & & Itide & & \\
\hline \multirow{2}{*}{ 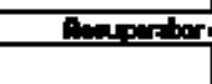 } & 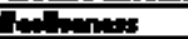 & & ot? & $\mathrm{Hit}$ & it: & 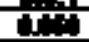 & $s^{4}$ & ini & tit? & 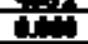 & DE & $\omega$ & $t$ & \\
\hline & 14: & & $7 ! !$ & FI:T & ITI & 75 & 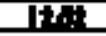 & I.1. & A.R & I. & FI: & TS1 & 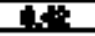 & $F T:$ \\
\hline \multirow{4}{*}{ 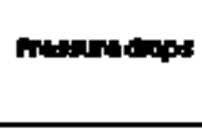 } & Bemparar & & 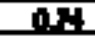 & 154 & In & 91 & 1 & $|F|$ & 1! L & $M$ & $1+1$ & $4 \mathrm{~s}$ & $!$ & $1+$ \\
\hline & II & & 11 & 21 & 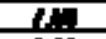 & 11. & ता1 & 14 & III & $7 !$ & 21 & I!! & 7 & 4 \\
\hline & & & 1. & & ?!I & $1 / 4$ & 58 & 11 & $m \pi$ & 24 & 4 & 79 & 78 & 54 \\
\hline & 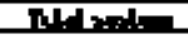 & & III & $m$ & F.1: & 11.2 & 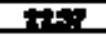 & +7 & $7 \Omega$ & 1.7 & $\min$ & $7:$ & 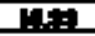 & 74 \\
\hline \multirow{4}{*}{ 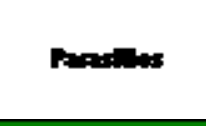 } & E! & & 11 & 12 & 19 & 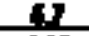 & 1.2 & 49 & 1. & 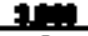 & $18:$ & 1.1 & nte & $17 \pi$ \\
\hline & 19 & & $1 \%$ & & & 17 & 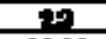 & 172 & $1 \ldots$ & 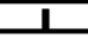 & 1 & $1 \%$ & 1. & 17 \\
\hline & A. & 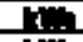 & $3 ! 1$ & 1. & 11 & $\mathrm{Fln}$ & [n.4. & $7.1 \%$ & $1 \ldots$ & 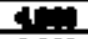 & $78 !$ & $3 \pi$ & nta & \\
\hline & Tft-1 & $\mathrm{Fin}$ & $n$ & DI & 210 & 27 & 29 & $m \pi$ & 17 & II & Fin & 10 & 물 & 71 \\
\hline \multirow{4}{*}{ Energy flows } & Fuel & $\mathrm{kw}$ & 1133 & 232.4 & 393.8 & 330.9 & 6792 & 1150.6 & 86.7 & 178.1 & 248.1 & 250.7 & 515.5 & 7179 \\
\hline & Cell & kWe & 49.6 & 95.1 & 140.7 & 148.9 & 285 & 421.5 & 48.4 & 92.4 & 118.6 & 145.2 & 277 & 355.5 \\
\hline & Stack DC & kwe & 4930 & 93.7 & 1365 & 148.60 & 283.5 & 417.2 & 48 & 90.9 & 115.8 & 144.8 & 275.6 & 352.7 \\
\hline & Net $\mathrm{AC}$ & kwe & 42,40 & 80.5 & 111.5 & 128.40 & 2448 & 344.4 & 42.2 & 81 & 101.4 & 129.8 & 248.3 & 3123 \\
\hline \multirow{3}{*}{ Efficiencies } & Cell & $\%$ & 43.8 & 409 & 35.8 & 450 & 42.0 & 36.6 & 55.8 & 51.9 & 47.8 & 579 & 53.7 & 49.5 \\
\hline & Stack DC & $\%$ & 43.5 & 403 & 34.7 & 449 & 41.7 & 363 & 55.4 & 51.0 & 46.7 & 578 & 535 & 49.1 \\
\hline & Net $\mu \mathrm{LL}$ & 电 & 37.4 & 34.6 & 28.3 & 38.8 & 36.0 & 299 & 48.8 & 45.5 & 40.9 & 518 & $48 z$ & 43.5 \\
\hline
\end{tabular}

Table 1.6 - Syngas Performance Summary for the 95 kWe-Class Test Article and 285 kWe-class Advanced Module 


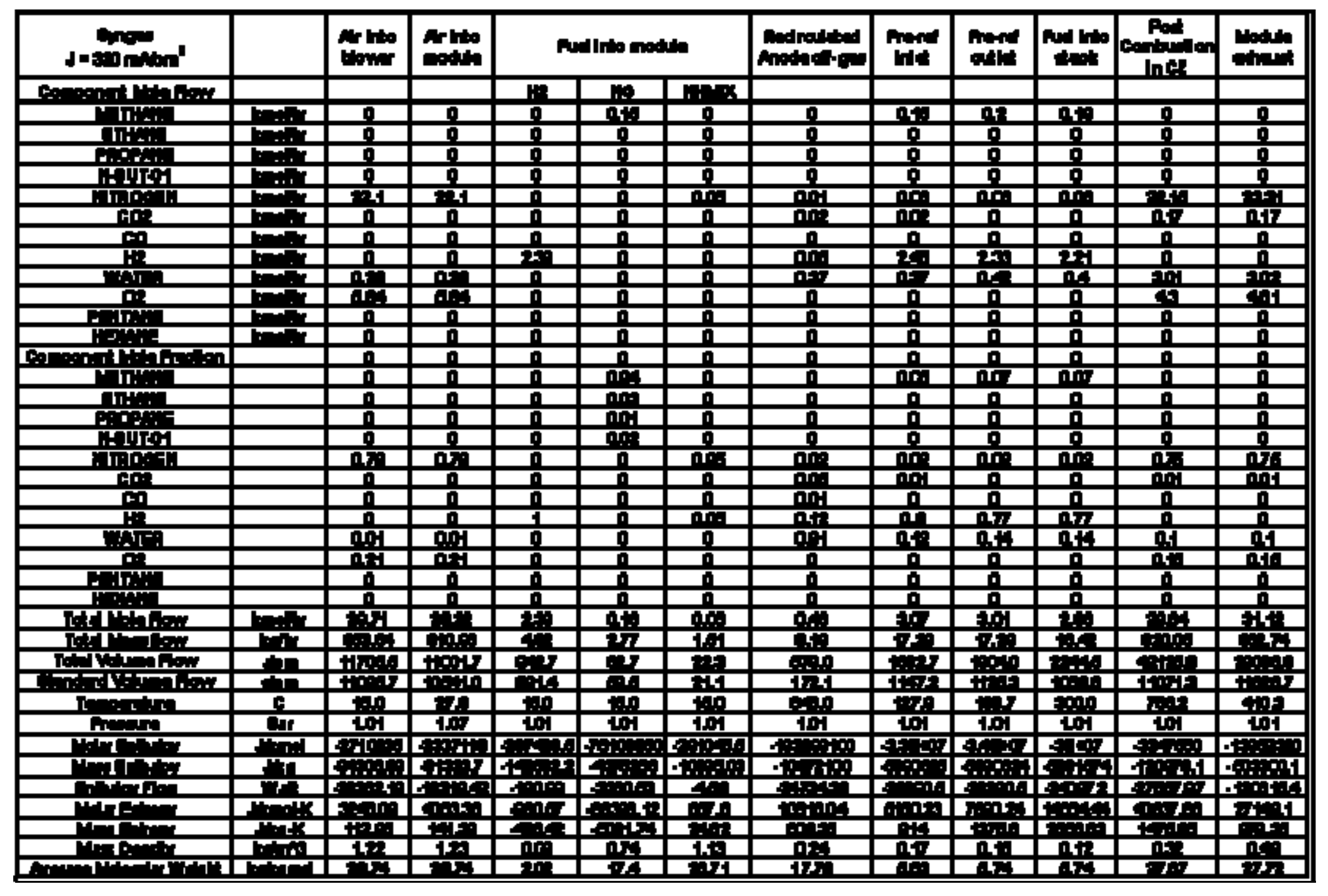

Table 1.7 - Statepoints for the 95 kWe-Class Test Article (Syngas fuel, I = 834 A) 


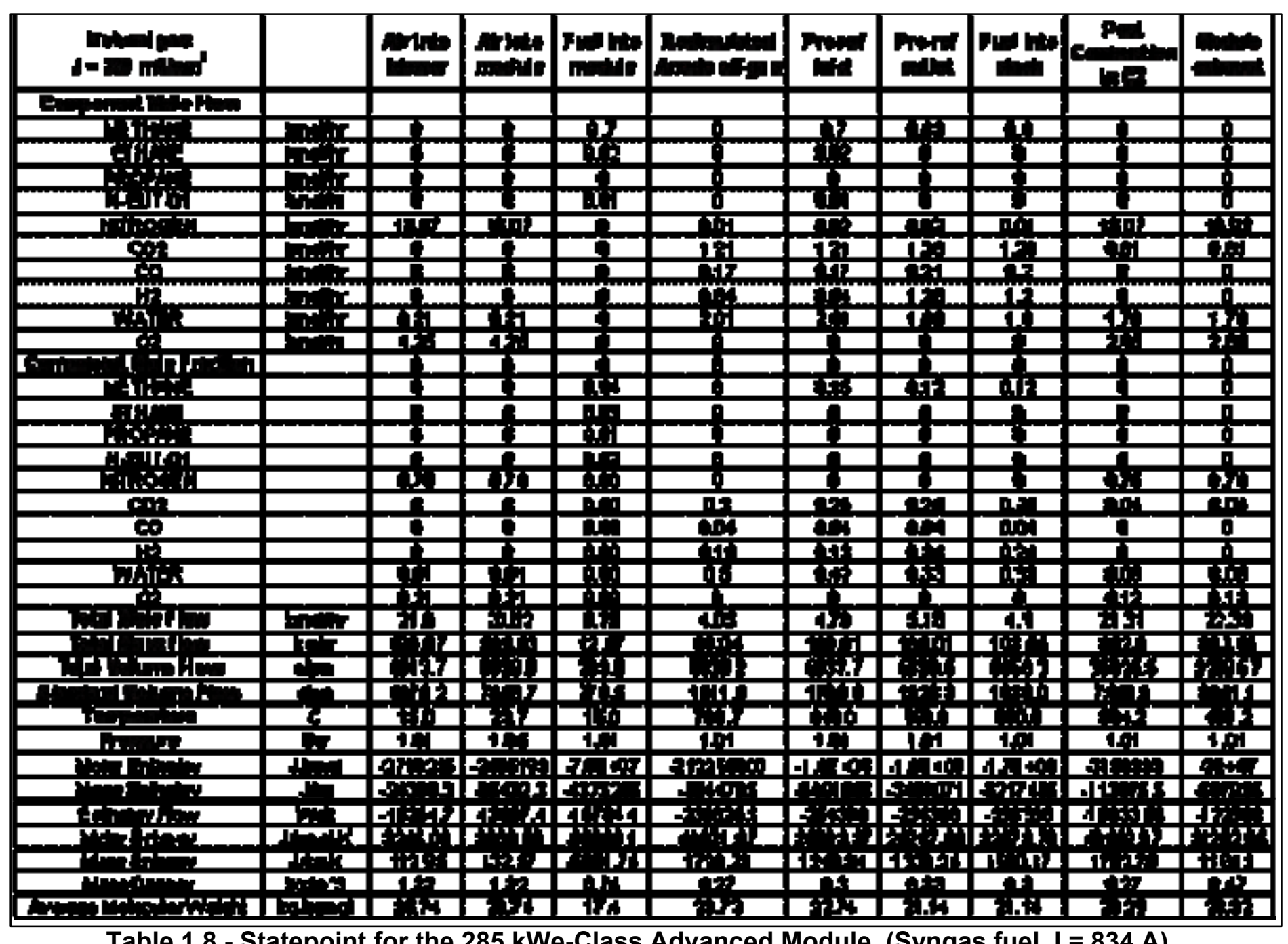

Table 1.8 - Statepoint for the 285 kWe-Class Advanced Module (Syngas fuel, I = 834 A) 


\begin{tabular}{|c|c|c|c|c|c|}
\hline & & $\mathrm{mIn}$ & Lat & & 5 \\
\hline$a_{-11: 1}$ & $9 \sin ^{2}$ & Fi & 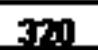 & 90 & $3 ?$ \\
\hline chn & $\mathbf{A}$ & $1+52$ & (1D.6) & $1+92$ & $0 x$ \\
\hline IEm:ar: & & & & & \\
\hline & c: & प्राम & 912 & YFil1 & 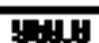 \\
\hline & & OTI8 & 3993 & 993 & \\
\hline $9 \mathrm{Mi}$ & Vol:3 & DEti & 1707 & Divi2 & a. \\
\hline axt? & & & & & \\
\hline & & $7 ! 5$ & 19.1 & 313 & t \\
\hline & 8 & n2 & De & DO & E \\
\hline & & & & & \\
\hline & & 391 & 332 & 35 & 3ㄴ.1 \\
\hline & & -158 & -148 & -5.3 & -11 \\
\hline Desestich & & & & & \\
\hline & & nax & $n=2$ & -ni & $n ! ! n$ \\
\hline & 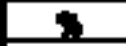 & -1.5 .1 & $=n$ & -1.09 & -013 \\
\hline actlew & & & & & \\
\hline & 7 & $1 n !$ & 9.2 & 0.14 & E1 \\
\hline & 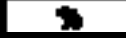 & -24 & $-2 I$ & -3.3 & -23 \\
\hline
\end{tabular}

Table 1.9 - Flow Maldistributions for a Ten Bundle Row, Syngas Fuel at Different Currents with and without an Air Inlet Orifice

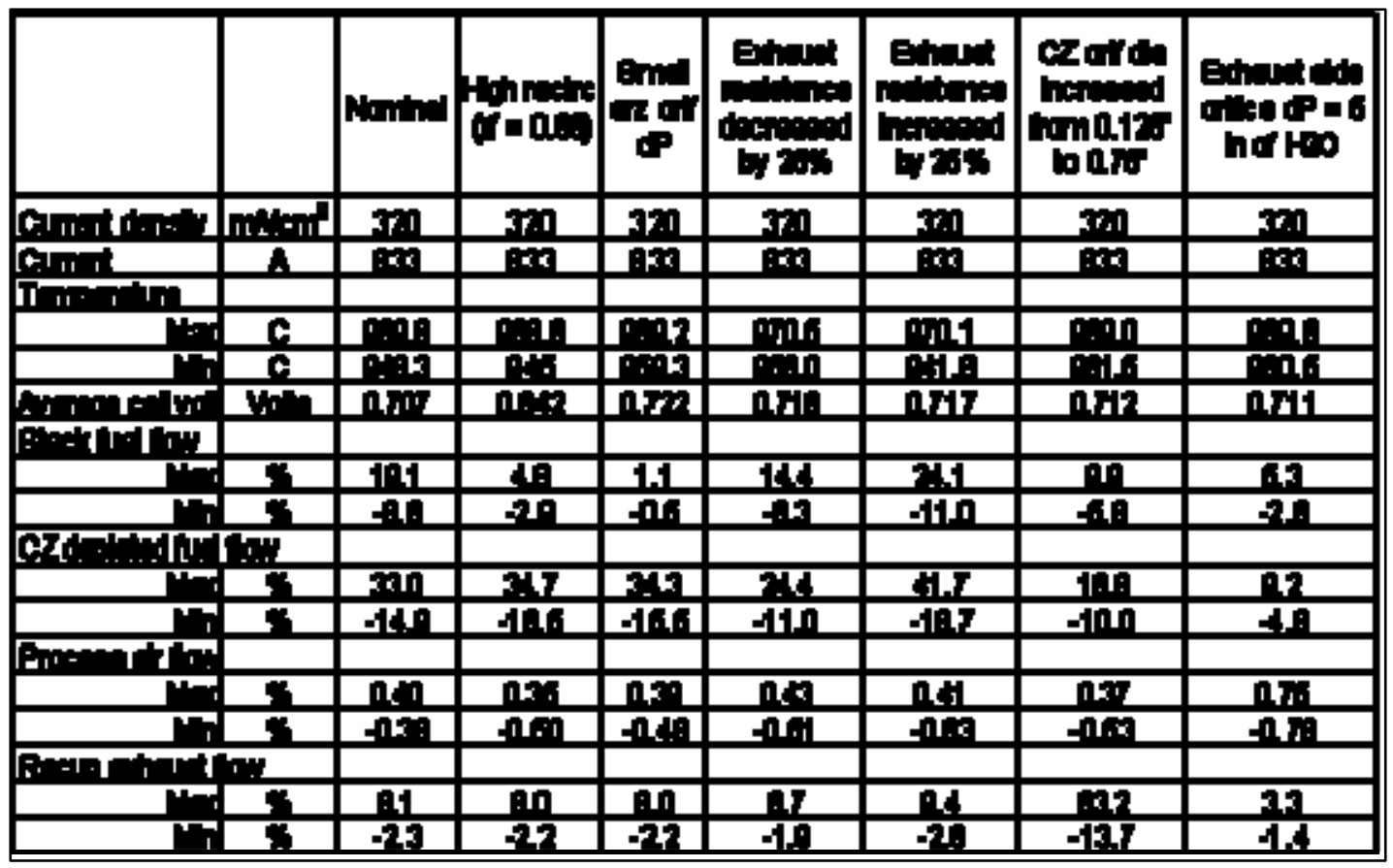

Figure 1.10 - Sensitivity of Flow Maldistributions for a Ten Bundle Row, Syngas Fuel to Different Model Parameters 


\begin{tabular}{|c|c|c|c|c|c|c|c|}
\hline \multirow[b]{2}{*}{ 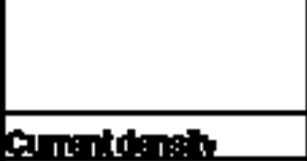 } & \multirow[b]{2}{*}{$\operatorname{mon} \ln ^{2}$} & \multicolumn{3}{|c|}{ Mhathatones } & \multicolumn{3}{|c|}{ Mnot athatodea } \\
\hline & & 90 & 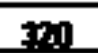 & $1 F_{1}$ & $\because 1$ & 3 & \\
\hline sin: & $\mathbf{A}$ & $11 H$ & ES & 391 & 117 & DES & 391 \\
\hline \multicolumn{8}{|l|}{ 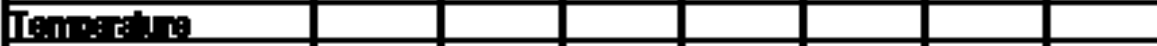 } \\
\hline & $\bar{c}$ & 927 & $\operatorname{con} \theta$ & mono & 800 & mit & 002 \\
\hline & $\mathbf{c}$ & 96 & 9179 & 991 & get? & 978 & 996 \\
\hline \multirow{3}{*}{ 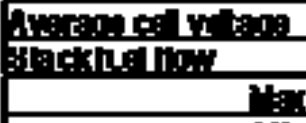 } & Vit.:- & n[Fta & neta & $n \pi$ & not: & nen: & n7min \\
\hline & & & & & & & \\
\hline & & A.7 & 73 & 5.3 & A7 & 73 & G4 \\
\hline لب & 눈 & 37 & $2 \mathrm{~A}$ & -71 & -37 & -79 & 97 \\
\hline \multicolumn{8}{|l|}{ 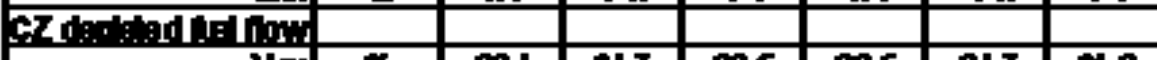 } \\
\hline & 5 & 294 & 217 & 215 & 292 & 217 & 혀2 \\
\hline & 5 & -121 & $\because 1 F$ & -919 & -124 & -18 & $-[0,3$ \\
\hline \multicolumn{8}{|l|}{ Pmeasesthy } \\
\hline & & $n=2$ & $\overline{112}$ & $\ln$ & $n$ n!E & n.19 & $\bar{T}$ \\
\hline h & 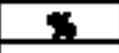 & $-n .9$ & \pm 19 & -154 & fn: & \pm 2.3 & -189 \\
\hline \multicolumn{8}{|l|}{ 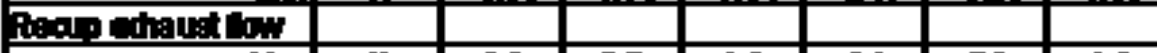 } \\
\hline & 3 & $9 !$ & $T /$ & 49 & 91 & $7 !$ & 4. \\
\hline 근 & 3 & -24 & 49 & -109 & -25 & -19 & 00 \\
\hline
\end{tabular}

Figure 1.11 - Flow Maldistributions for a Ten Bundle Row, Natural Gas Fuel at Different Currents with and without an Air Inlet Orifice

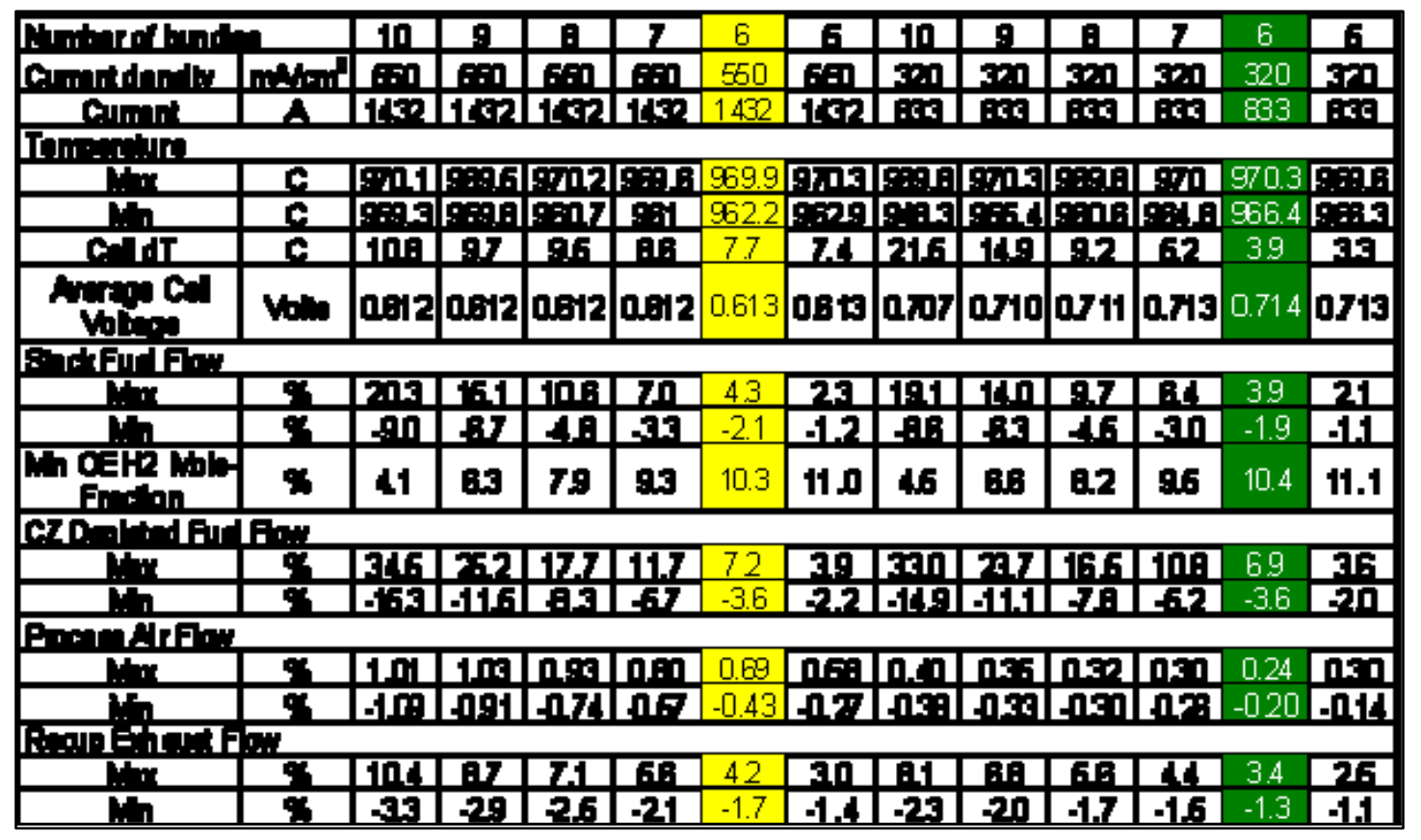

Figure 1.12 - Flow Maldistributions Variation with Number of Bundles in a Row (Syngas Fuel) 


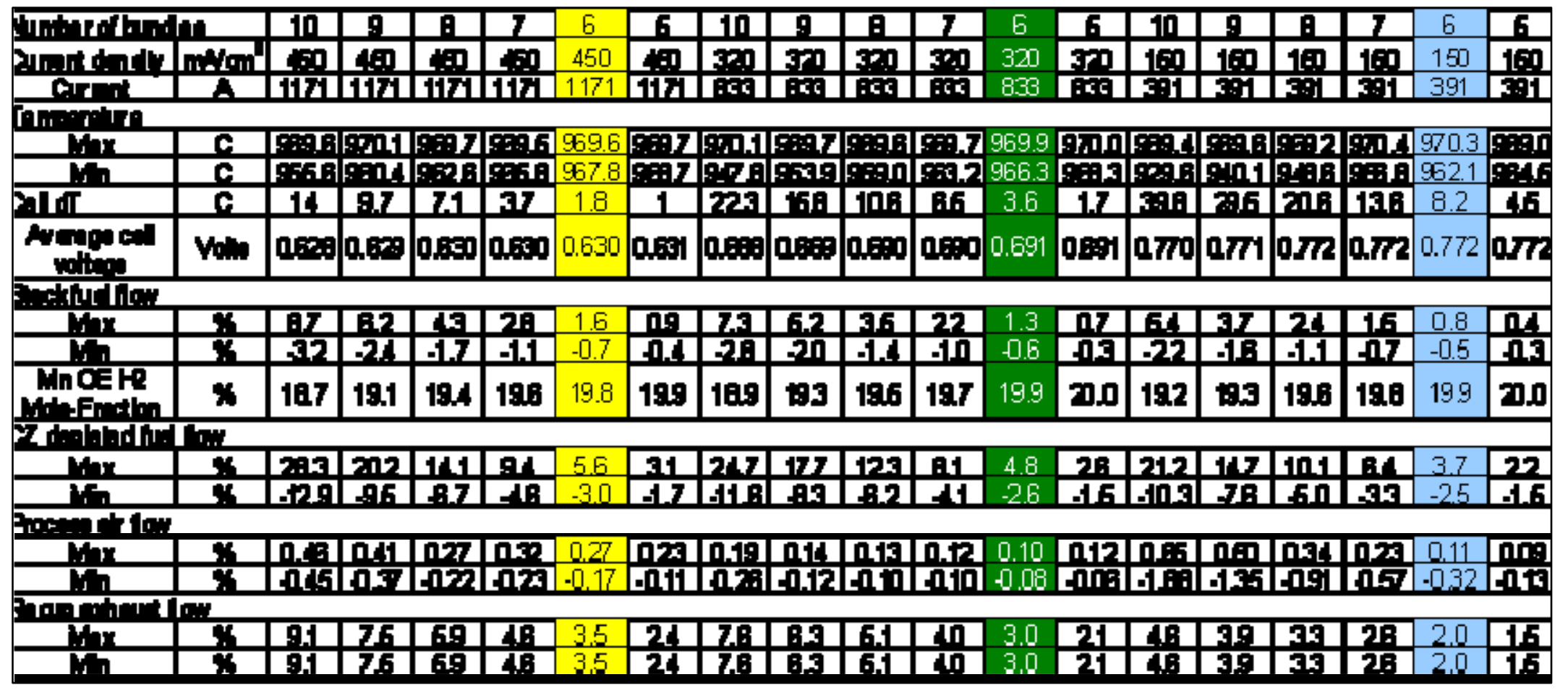

Table 1.13 - - Flow Maldistributions Variation with Number of Bundles in a Row (Natural Gas Fuel) 


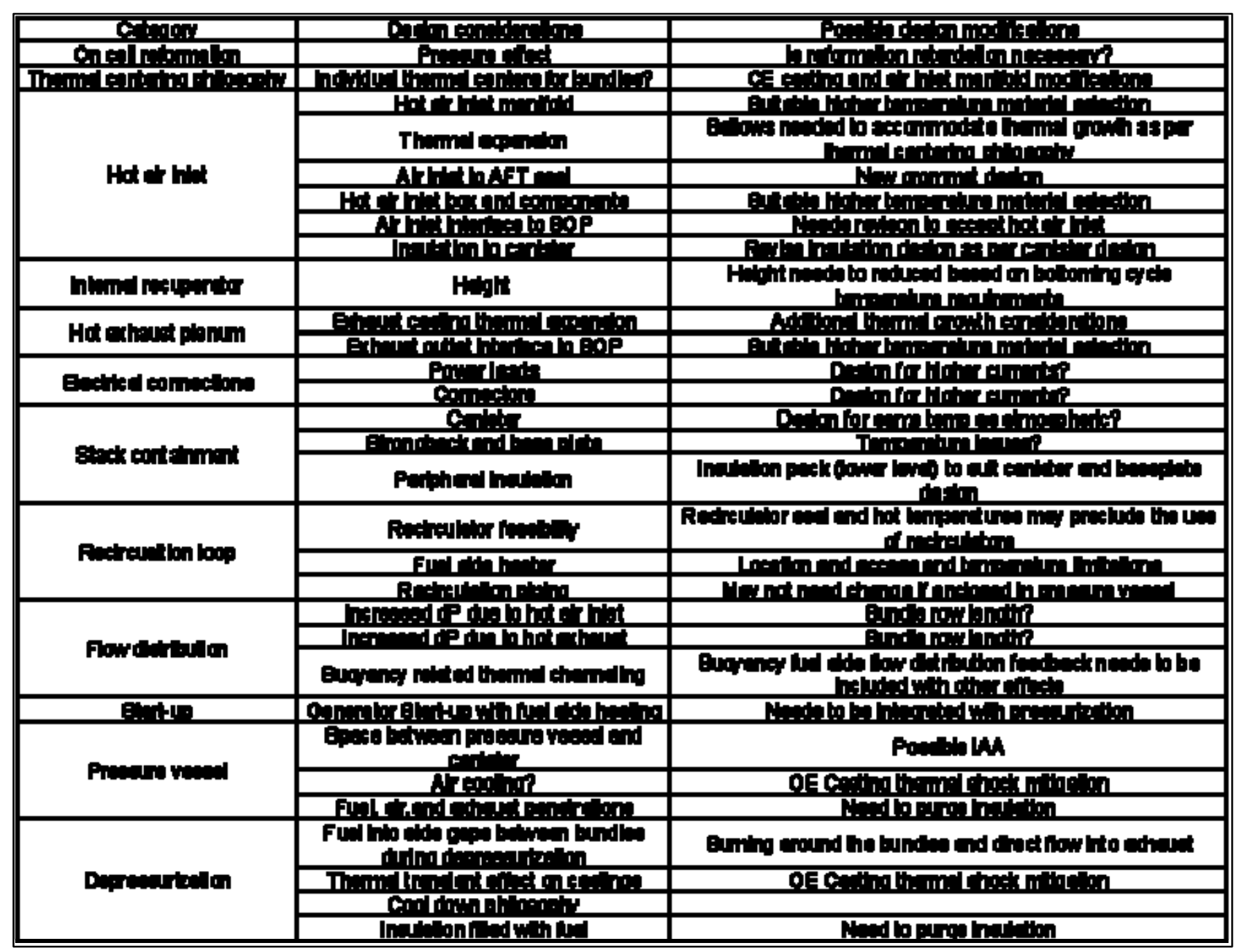

Table 1.14 - List of Module Design and Analysis Issues Associated with Pressurized Operation 